\title{
Modulation of Proton-Coupled Electron Transfer through Molybdenum-quinonoid Interactions
}

Justin T. Henthorn and Theodor Agapie*

Division of Chemistry and Chemical Engineering, California Institute of Technology, Pasadena, CA 91125

\section{Experimental Details}

General Considerations

Synthesis of bis(benzo-15-crown-5)potassium [1,4-bis(2-(diisopropylphosphino)phenyl)-2,3semicatecholate]tricarbonylmolybdenum $(0)(9)$

Synthesis of bis(benzo-15-crown-5)potassium [1,4-bis(2-bromophenyl)-2,3-semicatecholate] (10)

Synthesis of 1,4-bis(2-bromophenyl)-2,3-quinone (11)

General Procedure for $\mathrm{pK}_{\mathrm{a}}$ determination of compound 1, 2, 3, and 8

Reactions of $\mathbf{1}, \mathbf{2}$, and $\mathbf{8}$ with TEMPO

II. Nuclear Magnetic Resonance Spectra

Figure S1. ${ }^{1} \mathrm{H}$ NMR spectrum of 2 in $\mathrm{CD}_{3} \mathrm{CN}$ at $25^{\circ} \mathrm{C}$

Figure $\mathbf{S 2} .{ }^{13} \mathrm{C}\left\{{ }^{1} \mathrm{H}\right\}$ NMR spectrum of 2 in $\mathrm{CD}_{3} \mathrm{CN}$ at $25^{\circ} \mathrm{C} \quad \mathrm{S} 9$

Figure S3. ${ }^{31} \mathrm{P}\left\{{ }^{1} \mathrm{H}\right\}$ NMR spectrum of 2 in $\mathrm{CD}_{3} \mathrm{CN}$ at $25^{\circ} \mathrm{C} \quad$ S9

Figure S4. ${ }^{19} \mathrm{~F}$ NMR spectrum of 2 in $\mathrm{CD}_{3} \mathrm{CN}$ at $25^{\circ} \mathrm{C} \quad \mathrm{S} 10$

Figure S5. ${ }^{1} \mathrm{H}$ NMR spectrum of 3 in $\mathrm{CD}_{3} \mathrm{CN}$ at $25^{\circ} \mathrm{C} \quad \mathrm{S} 10$

Figure S6. ${ }^{13} \mathrm{C}\left\{{ }^{1} \mathrm{H}\right\}$ NMR spectrum of $\mathbf{3}$ in $\mathrm{CD}_{3} \mathrm{CN}$ at $25^{\circ} \mathrm{C} \quad \mathrm{S} 10$

Figure S7. ${ }^{31} \mathrm{P}\left\{{ }^{1} \mathrm{H}\right\}$ NMR spectrum of $\mathbf{3}$ in $\mathrm{CD}_{3} \mathrm{CN}$ at $25^{\circ} \mathrm{C} \quad \mathrm{S} 11$

Figure S8. ${ }^{19} \mathrm{~F}$ NMR spectrum of $\mathbf{3}$ in $\mathrm{CD}_{3} \mathrm{CN}$ at $25^{\circ} \mathrm{C} \quad \mathrm{S} 11$

Figure S9. ${ }^{1} \mathrm{H}$ NMR spectrum of $\mathbf{5 a}$ and $\mathbf{5 b}$ in $\mathrm{CD}_{3} \mathrm{CN}$ at $25^{\circ} \mathrm{C} \quad \mathrm{S} 11$

Figure S10. ${ }^{13} \mathrm{C}\left\{{ }^{1} \mathrm{H}\right\}$ NMR spectrum of $\mathbf{5 a}$ and $\mathbf{5 b}$ in $\mathrm{CD}_{3} \mathrm{CN}$ at $25^{\circ} \mathrm{C} \quad \mathrm{S} 12$

Figure S11. ${ }^{31} \mathrm{P}\left\{{ }^{1} \mathrm{H}\right\}$ NMR spectrum of $\mathbf{5 a}$ and $\mathbf{5 b}$ in $\mathrm{CD}_{3} \mathrm{CN}$ at $25^{\circ} \mathrm{C} \quad \mathrm{S} 12$

Figure S12. ${ }^{19} \mathrm{~F}$ NMR spectrum of $\mathbf{5 a}$ and $\mathbf{5 b}$ in $\mathrm{CD}_{3} \mathrm{CN}$ at $25{ }^{\circ} \mathrm{C} \quad \mathrm{S} 12$

Figure S13. ${ }^{1} \mathrm{H}$ NMR spectrum of 6 in $\mathrm{CD}_{2} \mathrm{Cl}_{2}$ at $25^{\circ} \mathrm{C} \quad \mathrm{S} 13$

Figure S14. ${ }^{13} \mathrm{C}\left\{{ }^{1} \mathrm{H}\right\}$ NMR spectrum of 6 in $\mathrm{CD}_{2} \mathrm{Cl}_{2}$ at $25^{\circ} \mathrm{C} \quad \mathrm{S} 13$

Figure S15. ${ }^{31} \mathrm{P}\left\{{ }^{1} \mathrm{H}\right\}$ NMR spectrum of 6 in $\mathrm{CD}_{2} \mathrm{Cl}_{2}$ at $25^{\circ} \mathrm{C} \quad \mathrm{S} 13$

Figure S16. ${ }^{1} \mathrm{H}$ NMR spectrum of 9 in $\mathrm{CD}_{3} \mathrm{CN}$ at $25{ }^{\circ} \mathrm{C} \quad \mathrm{S} 14$

Figure S17. ${ }^{13} \mathrm{C}\left\{{ }^{1} \mathrm{H}\right\}$ NMR spectrum of 9 in $\mathrm{CD}_{3} \mathrm{CN}$ at $25^{\circ} \mathrm{C} \quad \mathrm{S} 14$

Figure S18. ${ }^{31} \mathrm{P}\left\{{ }^{1} \mathrm{H}\right\}$ NMR spectrum of 9 in $\mathrm{CD}_{3} \mathrm{CN}$ at $25^{\circ} \mathrm{C} \quad \mathrm{S} 14$

Figure S19. ${ }^{1} \mathrm{H}$ NMR spectrum of 10 in $\mathrm{CD}_{3} \mathrm{CN}$ at $25^{\circ} \mathrm{C} \quad \mathrm{S} 15$

Figure S20. ${ }^{13} \mathrm{C}\left\{{ }^{1} \mathrm{H}\right\}$ spectrum of $\mathbf{1 0}$ in $\mathrm{CD}_{3} \mathrm{CN}$ at $25^{\circ} \mathrm{C} \quad \mathrm{S} 15$

Figure S21. ${ }^{1} \mathrm{H}$ NMR spectrum of 11 in $\mathrm{CDCl}_{3}$ at $25^{\circ} \mathrm{C} \quad \mathrm{S} 15$

Figure S22. ${ }^{13} \mathrm{C}\left\{{ }^{1} \mathrm{H}\right\}$ spectrum of 11 in $\mathrm{CDCl}_{3}$ at $25^{\circ} \mathrm{C} \quad \mathrm{S} 16$

Figure S23. ${ }^{1} \mathrm{H}$ and ${ }^{31} \mathrm{P}\left\{{ }^{1} \mathrm{H}\right\}$ NMR spectra of 1 and 2 equiv. TEMPO in $\mathrm{CD}_{3} \mathrm{CN}$ at $25^{\circ} \mathrm{C} \quad \mathrm{S} 16$

Figure S24. ${ }^{1} \mathrm{H}$ and ${ }^{31} \mathrm{P}\left\{{ }^{1} \mathrm{H}\right\}$ NMR spectra of 2 and 2 equiv. TEMPO in $\mathrm{CD}_{3} \mathrm{CN}$ at $25^{\circ} \mathrm{C} \quad \mathrm{S} 16$

Figure S25. ${ }^{1} \mathrm{H}$ NMR spectrum of 8 and 2 equiv. TEMPO in $\mathrm{CD}_{3} \mathrm{CN}$ at $25^{\circ} \mathrm{C} \quad \mathrm{S} 17$

Figure S26. ${ }^{1} \mathrm{H}$ NMR spectra of $\mathbf{1 1}$ and 2 equiv. TEMPOH in $\mathrm{CD}_{3} \mathrm{CN}$ at $25{ }^{\circ} \mathrm{C}$.

Figure S27. ${ }^{1} \mathrm{H}$ NMR spectra of equilibrium mixtures of 9 and $4-{ }^{t} \mathrm{BuPhOH}, 2$ and $2-\mathrm{NO}_{2} \mathrm{PhNH}_{2}, 3$ and $\mathrm{DABCO}$, and 10 and $4-{ }^{t} \mathrm{BuPhOH}$ in $\mathrm{CD}_{3} \mathrm{CN}$ at $25^{\circ} \mathrm{C}$

\section{Estimation of $O-H B D F E$}

Table S1. Thermochemical data for selected quinonoid compounds. Note that 1, 2, and $\mathbf{3}$ show irreversible redox events by cyclic voltammetry. 
IV. Crystallographic Information

Refinement Details

Table S2. Crystal and Refinement data for $\mathbf{3}, \mathbf{5} \mathbf{a} \bullet \mathbf{2 M e C N}, \mathbf{5 b}$, and 6

Figure S26. Structural drawing of $\mathbf{3}$

Figure S27. Structural drawing of 5a

Figure S28. Structural drawing of $\mathbf{5 b}$

$\mathrm{S} 22$

Figure S29. Structural drawing of 6 


\section{Experimental Details}

\section{General considerations:}

Unless indicated otherwise, reactions performed under inert atmosphere were carried out in oven-dried glassware in a glovebox under a nitrogen atmosphere purified by circulation through RCI-DRI 13X-0408 Molecular Seives 13X, 4x8 Mesh Beads and BASF PuriStar ${ }^{\circledR}$ Catalyst R3-11G, $5 \times 3$ mm (Research Catalysts, Inc.). Solvents for all reactions were purified by Grubbs' method. ${ }^{1} \mathrm{CD}_{3} \mathrm{CN}$ and $\mathrm{CD}_{2} \mathrm{Cl}_{2}$ were purchased from Cambridge Isotope Laboratories and distilled from $\mathrm{CaH}_{2}$ prior to use. Alumina and Celite were activated by heating under vacuum at $200{ }^{\circ} \mathrm{C}$ for 24 hours. ${ }^{1} \mathrm{H},{ }^{19} \mathrm{~F}$, and ${ }^{31} \mathrm{P} \mathrm{NMR}$ spectra were recorded on Varian Mercury $300 \mathrm{MHz}$ spectrometers at ambient temperature, unless denoted otherwise. ${ }^{13} \mathrm{C}$ NMR spectra were recorded on a Varian INOVA-500 MHz spectrometer. ${ }^{1} \mathrm{H}$ and ${ }^{13} \mathrm{C}$ NMR chemical shifts are reported with respect to internal solvent: $1.94 \mathrm{ppm}$ and 118.26 for $\mathrm{CD}_{3} \mathrm{CN}$, and $5.32 \mathrm{ppm}$ and 53.84 ppm for $\mathrm{CD}_{2} \mathrm{Cl}_{2}$, respectively. ${ }^{19} \mathrm{~F}$ and ${ }^{31} \mathrm{P}$ NMR chemical shifts are reported with respect to an external standard of $\mathrm{C}_{6} \mathrm{~F}_{6}(-164.9 \mathrm{ppm})$ and $85 \% \mathrm{H}_{3} \mathrm{PO}_{4}(0.0 \mathrm{ppm})$.

Powder and thin film ATR-IR measurements were obtained by placing a powder or drop of solution of the complex on the surface of a Bruker APLHA ATR-IR spectrometer probe and allowing the solvent to evaporate (Platinum Sampling Module, diamond, OPUS software package) at $2 \mathrm{~cm}^{-1}$ resolution. Solution IR spectra were recorded on a Thermo-Fisher Scientific Nicolet 6700 FTIR spectrometer using a $\mathrm{CaF}_{2}$ plate solution cell. Fast atom bombardment-mass spectrometry (FAB-MS) analysis was performed with a JEOL JMS-600H high-resolution mass spectrometer. Gas chromatography-mass spectrometry (GC-MS) analysis was performed upon filtering the sample through a plug of silica gel. Electrochemical measurements were recorded with a Pine Instrument Company AFCBP1 bipotentiostat using the AfterMath software package. Cyclic voltammograms and square-wave voltammograms were recorded on ca. $2 \mathrm{mM}$ solutions of the relevant complex in the glovebox at $20{ }^{\circ} \mathrm{C}$ with an auxiliary Pt-coil electrode, a $\mathrm{Ag} / \mathrm{Ag}^{+}$reference electrode $\left(0.01 \mathrm{M} \mathrm{AgNO}, 0.1 \mathrm{M}\left[{ }^{n} \mathrm{Bu}_{4} \mathrm{~N}^{+}\right]\left[\mathrm{PF}_{6}{ }^{-}\right]\right.$in $\mathrm{MeCN}$ ), and a $3.0 \mathrm{~mm}$ glassy carbon electrode disc (BASI). The electrolyte solution was $0.1 \mathrm{M}\left[{ }^{n} \mathrm{Bu} 4 \mathrm{~N}^{+}\right]\left[\mathrm{PF}_{6}{ }^{-}\right]$in $\mathrm{MeCN}$. All reported values are referenced to an internal ferrocene/ferrocenium couple. Elemental analysis was conducted by Robertson Microlit Labs (Ledgewood, NJ).

Unless otherwise noted all chemical reagents were purchased from commercial sources and used without further purification. AgOTf, 2,3-dichloro-5,6-dicyano-1,4benzoquinone and benzo-15-crown-5 were purchased from Sigma Aldrich and used as received. 2,6-di-tert-butyl-4-methylpyridine, 4-tert-butylphenol, 2-nitroaniline, and [2,2,2]-diazobicyclooctane were purchased from Sigma Aldrich and sublimed prior to use. $\mathrm{PhICl}_{2},{ }^{2} \mathrm{BnK}^{3}{ }^{3} \mathbf{1}^{4} \mathbf{4}^{4}, \mathbf{8}^{4}$, and Fetizon's reagent $\left(\mathrm{Ag}_{2} \mathrm{CO}_{3} \text { on Celite }\right)^{5}$ were prepared using literature procedures. Assignments of NMR spectra are given corresponding to the following numbering scheme:

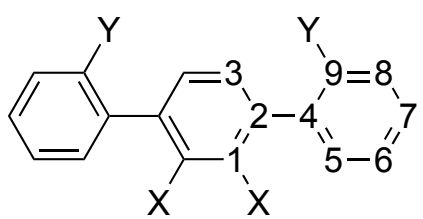




\section{Synthesis of bis(benzo-15-crown-5)potassium [1,4-bis(2-}

(diisopropylphosphino)phenyl)-2,3-semicatecholate]tricarbonylmolybdenum(0) (9)

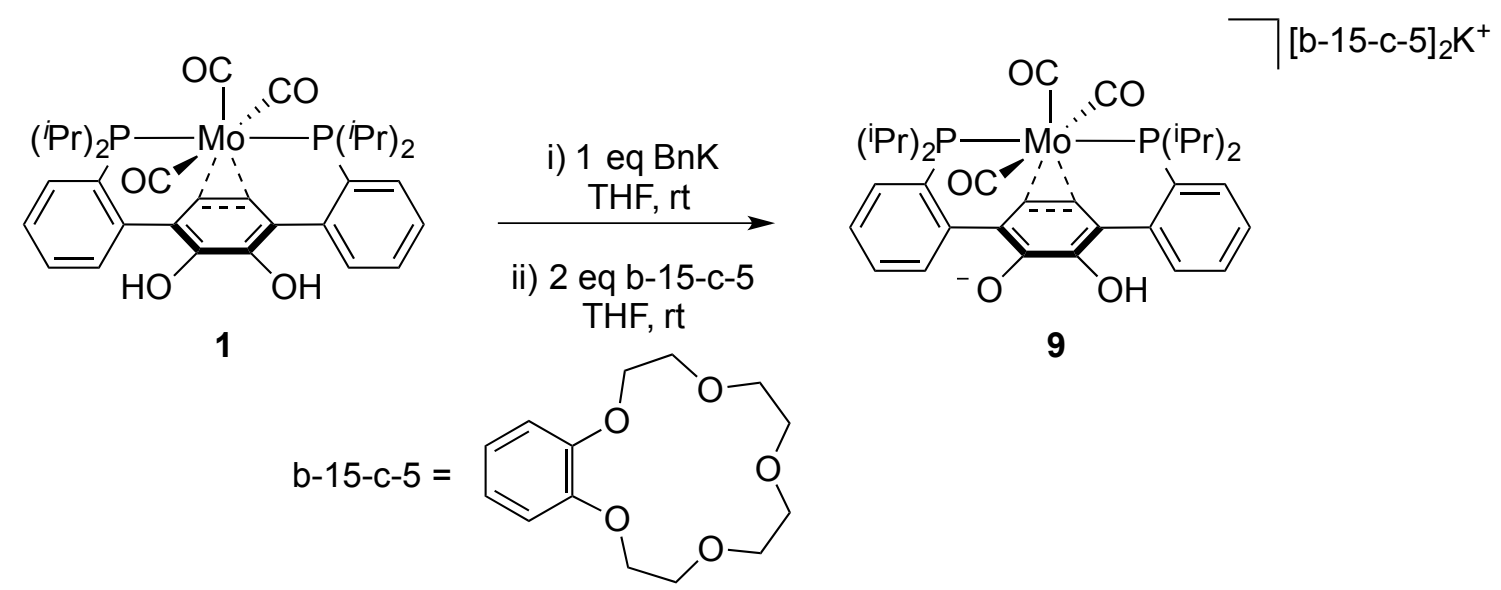

To a solution of $1(0.0623 \mathrm{~g}, 0.0924 \mathrm{mmol})$ in THF $(2 \mathrm{~mL})$ was added dropwise a solution of BnK $(0.0118 \mathrm{~g}, 0.0906 \mathrm{mmol})$ in THF $(2 \mathrm{~mL})$. Upon complete addition, a solution of benzo-15-crown-5 $(0.0507 \mathrm{~g}, 0.189 \mathrm{mmol})$ in THF $(2 \mathrm{~mL})$ and the mixture was stirred at room temperature for 30 minutes. The volatiles were then removed under reduced pressure, and the resulting residue was triturated with $\mathrm{Et}_{2} \mathrm{O}(5 \mathrm{~mL})$ and the solid collected on a pad of celite. The solid was then dissolved in benzene $(5 \mathrm{~mL})$, filtered through celite, and concentrated in vacuo to afford the desired product as an orange powder $(0.0756 \mathrm{~g}, 66 \%) .{ }^{1} \mathrm{H}$ NMR $\left(300 \mathrm{MHz}, \mathrm{CD}_{3} \mathrm{CN}, 25^{\circ} \mathrm{C}\right), \delta(\mathrm{ppm}): 9.22(\mathrm{~s}, \mathrm{br}, 1 \mathrm{H}$, O-H), 8.04 (d, 8 Hz, 2 H, Ar-CH), 7.91 (d, 8 Hz, 2 H, Ar-CH), 7.38 (t, 8 Hz, 2 H, Ar$\mathrm{CH}), 7.25(\mathrm{t}, 8 \mathrm{~Hz}, 2 \mathrm{H}, \mathrm{Ar}-\mathrm{CH}), 6.91(\mathrm{~m}, 2 \mathrm{H}$, crown $\mathrm{Ar}-\mathrm{CH}), 6.81(\mathrm{~m}, 2 \mathrm{H}$, crown Ar$\mathrm{CH}), 5.38\left(\mathrm{t}, 4.9 \mathrm{~Hz}, 2 \mathrm{H}\right.$, quinonoid $\left.\mathrm{Ar}_{-} \mathrm{C}_{3} \mathrm{H}\right), 3.91\left(\mathrm{~m}, 4 \mathrm{H}\right.$, crown $\left.\mathrm{O}-\mathrm{CH}_{2}\right), 3.66(\mathrm{~m}, 8$ $\mathrm{H}$, crown $\left.\mathrm{O}-\mathrm{CH}_{2}\right), 3.66\left(\mathrm{~m}, 8 \mathrm{H}\right.$, crown $\left.\mathrm{O}-\mathrm{CH}_{2}\right), 3.57\left(\mathrm{~m}, 4 \mathrm{H}\right.$, crown $\left.\mathrm{O}-\mathrm{CH}_{2}\right), 2.93(\mathrm{~m}$, $\left.2 \mathrm{H}, \mathrm{PCH}\left(\mathrm{CH}_{3}\right)_{2}\right), 2.48\left(\mathrm{~m}, 2 \mathrm{H}, \mathrm{PCH}\left(\mathrm{CH}_{3}\right)_{2}\right), 1.42\left(\mathrm{~m}, 6 \mathrm{H}, \mathrm{PCH}\left(\mathrm{CH}_{3}\right)_{2}\right), 1.31(\mathrm{~m}, 6 \mathrm{H}$, $\left.\mathrm{PCH}\left(\mathrm{CH}_{3}\right)_{2}\right), 0.96\left(\mathrm{~m}, 6 \mathrm{H}, \mathrm{PCH}\left(\mathrm{CH}_{3}\right)_{2}\right), 0.90\left(\mathrm{~m}, 6 \mathrm{H}, \mathrm{PCH}\left(\mathrm{CH}_{3}\right)_{2}\right) .{ }^{31} \mathrm{P}$ NMR $(121$ $\left.\mathrm{MHz}, \mathrm{CD}_{3} \mathrm{CN}, 25{ }^{\circ} \mathrm{C}\right), \delta(\mathrm{ppm}): 51.42(\mathrm{~s}) .{ }^{13} \mathrm{C}$ NMR $\left(126 \mathrm{MHz}, \mathrm{CD}_{3} \mathrm{CN}, 25{ }^{\circ} \mathrm{C}\right)$, $\delta(\mathrm{ppm}): 229.15$ (t, $10 \mathrm{~Hz}, \mathrm{Mo}-\mathrm{CO}), 216.66$ (t, $10 \mathrm{~Hz}, \mathrm{Mo}-\mathrm{CO}), 211.78$ (t, $10 \mathrm{~Hz}, \mathrm{Mo}-$ $\mathrm{CO}$ ), 149.80 (s, $\mathrm{Ar}-\mathrm{C}_{1}$ ), 148.65 (s, crown Ar- $\mathrm{C}-\mathrm{O}$ ), 133.03 (s, Ar-CH), 132.29 (s, Ar$\mathrm{CH}$ ), 131.73 (s, Ar-CH), 130.73 (s, Ar-CH), 128.59 (s, Ar-CH), 126.62 (s, Ar-CH), 124.95 (s, Ar-CH), 122.43 (s, crown $\mathrm{Ar}-\mathrm{CH}), 120.19$ (s, Ar- $\mathrm{C}$ ), 114.32 (s, crown $\mathrm{Ar}-\mathrm{CH}$ ), $86.58\left(\mathrm{~s}, \mathrm{C}_{3}\right), 69.49$ (s, crown $\left.\mathrm{O}-\mathrm{CH}_{2}\right), 68.75\left(\mathrm{~s}\right.$, crown $\left.\mathrm{O}-\mathrm{CH}_{2}\right), 68.26$ (s, crown $\mathrm{O}-$ $\mathrm{CH}_{2}$ ), 67.91 (s, crown $\left.\mathrm{O}-\mathrm{CH}_{2}\right), 34.65$ (t, $\left.\mathrm{PCH}\left(\mathrm{CH}_{3}\right)_{2}\right), 31.16$ (t, $\left.\mathrm{PCH}\left(\mathrm{CH}_{3}\right)_{2}\right), 20.31$ (t, $\left.\operatorname{PCH}\left(\mathrm{CH}_{3}\right)_{2}\right), 19.92\left(\mathrm{t}, \mathrm{PCH}\left(\mathrm{CH}_{3}\right)_{2}\right), 19.53\left(\mathrm{~s}, \mathrm{PCH}\left(\mathrm{CH}_{3}\right)_{2}\right), 19.52\left(\mathrm{~s}, \mathrm{PCH}\left(\mathrm{CH}_{3}\right)_{2}\right)$. IR (THF), $v_{\mathrm{CO}}\left(\mathrm{cm}^{-1}\right): 1875,1605$. Anal. Calcd for [9], $\mathrm{C}_{61} \mathrm{H}_{79} \mathrm{KMoO}_{15} \mathrm{P}_{2}: \mathrm{C}, 58.65 ; \mathrm{H}, 6.37$. Found: C, 57.33; H, 6.10 . 


\section{Synthesis of bis(benzo-15-crown-5)potassium [1,4-bis(2-bromophenyl)-2,3- semicatecholate] (10)}

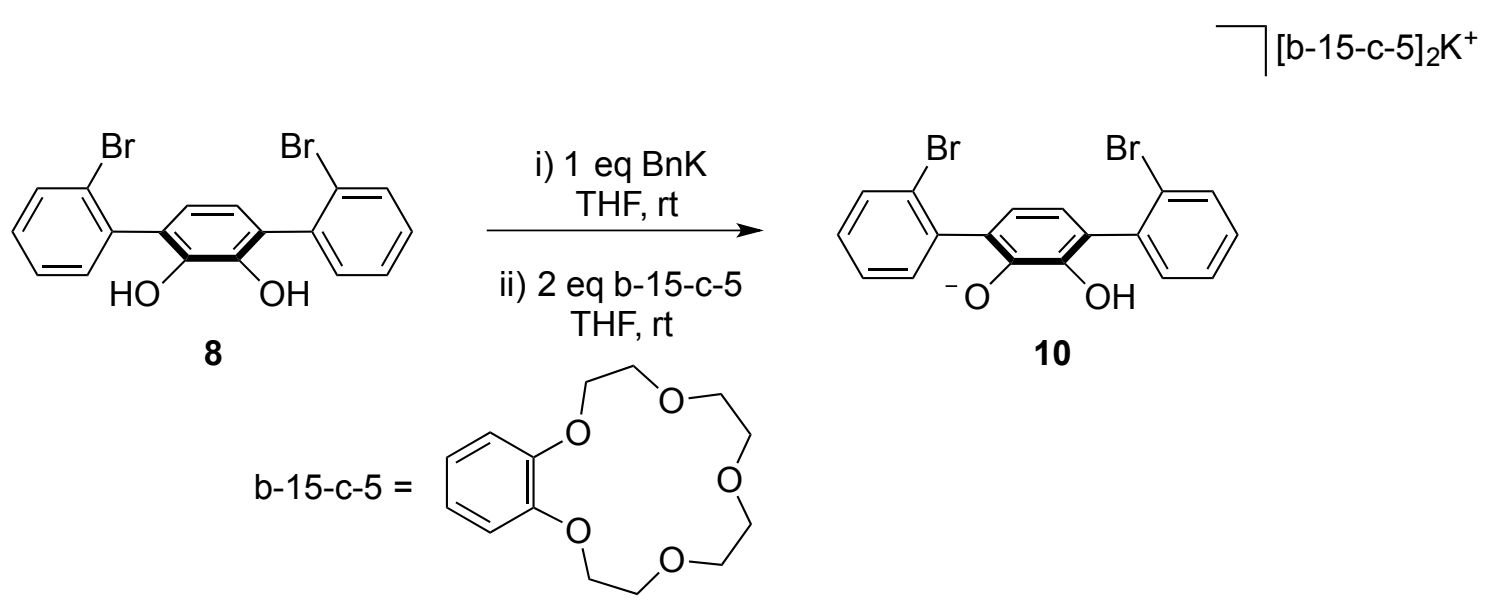

To a solution of $8(0.0998 \mathrm{~g}, 0.238 \mathrm{mmol})$ in THF $(2 \mathrm{~mL})$ was added dropwise a solution of BnK $(0.0309 \mathrm{~g}, 0.237 \mathrm{mmol})$ in THF $(2 \mathrm{~mL})$. Upon complete addition, a solution of benzo-15-crown-5 $(0.1351 \mathrm{~g}, 0.504 \mathrm{mmol})$ in THF $(2 \mathrm{~mL})$ and the mixture was stirred at room temperature for 30 minutes. The volatiles were then removed under reduced pressure, and the resulting residue was triturated with $\mathrm{Et}_{2} \mathrm{O}(5 \mathrm{~mL})$ and the solid collected on a pad of celite. The solid was then dissolved in benzene $(5 \mathrm{~mL})$, filtered through celite, and concentrated in vacuo to afford the desired product as an orange powder $(0.1213$, 51\%). ${ }^{1} \mathrm{H}$ NMR (300 MHz, $\mathrm{CD}_{3} \mathrm{CN}, 25^{\circ} \mathrm{C}$ ), $\delta(\mathrm{ppm}): 9.22$ (s, br, $\left.1 \mathrm{H}, \mathrm{O}-H\right), 8.04(\mathrm{~d}, 8$ $\mathrm{Hz}, 2 \mathrm{H}, \mathrm{Ar}-\mathrm{CH}$ ), 7.91 (d, $8 \mathrm{~Hz}, 2 \mathrm{H}, \mathrm{Ar}-\mathrm{CH}), 7.38$ (t, $8 \mathrm{~Hz}, 2 \mathrm{H}, \mathrm{Ar}-\mathrm{CH}), 7.25$ (t, 8 Hz, 2 $\mathrm{H}, \mathrm{Ar}-\mathrm{CH}), 6.91(\mathrm{~m}, 2 \mathrm{H}$, crown Ar-CH), $6.81(\mathrm{~m}, 2 \mathrm{H}$, crown Ar-CH), 5.38 (t, $4.9 \mathrm{~Hz}, 2$ $\mathrm{H}$, quinonoid $\left.\mathrm{Ar}_{-} \mathrm{C}_{3} \mathrm{H}\right), 3.91\left(\mathrm{~m}, 4 \mathrm{H}\right.$, crown $\left.\mathrm{O}-\mathrm{CH}_{2}\right), 3.66\left(\mathrm{~m}, 8 \mathrm{H}\right.$, crown $\left.\mathrm{O}-\mathrm{CH}_{2}\right), 3.66$ $\left(\mathrm{m}, 8 \mathrm{H}\right.$, crown $\left.\mathrm{O}-\mathrm{CH}_{2}\right), 3.57\left(\mathrm{~m}, 4 \mathrm{H}\right.$, crown $\left.\mathrm{O}-\mathrm{CH}_{2}\right), 2.93\left(\mathrm{~m}, 2 \mathrm{H}, \mathrm{PCH}\left(\mathrm{CH}_{3}\right)_{2}\right), 2.48$ $\left(\mathrm{m}, 2 \mathrm{H}, \mathrm{PCH}\left(\mathrm{CH}_{3}\right)_{2}\right), 1.42\left(\mathrm{~m}, 6 \mathrm{H}, \mathrm{PCH}\left(\mathrm{CH}_{3}\right)_{2}\right), 1.31\left(\mathrm{~m}, 6 \mathrm{H}, \mathrm{PCH}\left(\mathrm{CH}_{3}\right)_{2}\right), 0.96(\mathrm{~m}, 6$ $\left.\mathrm{H}, \mathrm{PCH}\left(\mathrm{CH}_{3}\right)_{2}\right), 0.90\left(\mathrm{~m}, 6 \mathrm{H}, \mathrm{PCH}\left(\mathrm{CH}_{3}\right)_{2}\right) .{ }^{31} \mathrm{P}$ NMR $\left(121 \mathrm{MHz}, \mathrm{CD}_{3} \mathrm{CN}, 25{ }^{\circ} \mathrm{C}\right)$, $\delta(\mathrm{ppm}): 51.42$ (s). ${ }^{13} \mathrm{C}$ NMR $\left(126 \mathrm{MHz}, \mathrm{CD}_{3} \mathrm{CN}, 25{ }^{\circ} \mathrm{C}\right), \delta(\mathrm{ppm}): 228.21$ (t, $10 \mathrm{~Hz}, \mathrm{Mo}-$ CO), 215.71 (t, $10 \mathrm{~Hz}, \mathrm{Mo}-\mathrm{CO}$ ), 210.83 (t, $10 \mathrm{~Hz}, \mathrm{Mo}-\mathrm{CO}$ ), 148.86 (s, Ar- $C_{1}$ ), 147.70 (s, crown $\mathrm{Ar}-\mathrm{C}-\mathrm{O}$ ), 132.09 (m), 131.35 (s, Ar-CH), 130.79 (s, Ar-CH), 129.78 (s, Ar-CH), 127.64 (s, Ar-CH), 125.68 (s, Ar-CH), 124.00 (s, Ar-CH), 121.48 (s, crown $\mathrm{Ar}-\mathrm{CH}$ ), 113.37 (s, crown $\mathrm{Ar}-\mathrm{CH}$ ), 85.63 (s, $\mathrm{C}_{3}$ ), 68.55 (s, crown $\mathrm{O}-\mathrm{CH}_{2}$ ), 67.81 (s, crown $\mathrm{O}-$ $\mathrm{CH}_{2}$ ), 67.32 (s, crown $\left.\mathrm{O}-\mathrm{CH}_{2}\right), 66.96$ (s, crown $\left.\mathrm{O}-\mathrm{CH}_{2}\right), 33.70\left(\mathrm{t}, \mathrm{PCH}\left(\mathrm{CH}_{3}\right)_{2}\right), 30.22$ (t, $\left.\mathrm{PCH}\left(\mathrm{CH}_{3}\right)_{2}\right), 19.37\left(\mathrm{t}, \mathrm{PCH}\left(\mathrm{CH}_{3}\right)_{2}\right), 18.98\left(\mathrm{t}, \mathrm{PCH}\left(\mathrm{CH}_{3}\right)_{2}\right), 18.58\left(\mathrm{~s}, \mathrm{PCH}\left(\mathrm{CH}_{3}\right)_{2}\right), 18.57$ (s, $\left.\mathrm{PCH}\left(\mathrm{CH}_{3}\right)_{2}\right)$. Anal. Calcd for [3], $\mathrm{C}_{46} \mathrm{H}_{51} \mathrm{Br}_{2} \mathrm{KO}_{12}$ : C, 55.54; H, 5.17. Found: $\mathrm{C}, 54.15$; H, 5.33. 
Synthesis of 3,6-bis(2-bromophenyl)-1,2-benzoquinone (11)
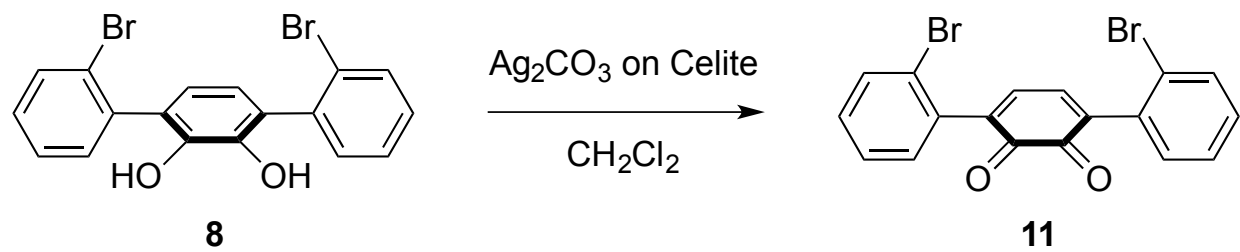

A round bottom flask was charged with $8(200 \mathrm{mg}, 0.476 \mathrm{mmol})$ dissolved in $\mathrm{CH}_{2} \mathrm{Cl}_{2}$ (40 $\mathrm{mL})$. Silver carbonate on Celite $\left(2.23 \mathrm{~g}, 3.90 \mathrm{mmol}, 1.75 \mathrm{mmol} \mathrm{Ag}_{2} \mathrm{CO}_{3} / \mathrm{g}\right)$ was added with stirring. The reaction was allowed to stir for 30 minutes at room temperature. The reaction was then filtered over a pad of Celite and the filtrate concentrated in vacuo to yield a red-orange solid (198 mg, 99\%). ${ }^{1} \mathrm{H}$ NMR $\left(300 \mathrm{MHz}, \mathrm{CDCl}_{3}, 25^{\circ} \mathrm{C}\right), \delta(\mathrm{ppm})$ : $7.72-7.61(\mathrm{~m}, 2 \mathrm{H}, \mathrm{Ar}-\mathrm{CH}), 7.43-7.24(\mathrm{~m}, 6 \mathrm{H}, \mathrm{Ar}-\mathrm{CH}), 7.13$ (s, $\left.2 \mathrm{H}, \mathrm{Ar}_{-} \mathrm{C}_{3} H\right) .{ }^{13} \mathrm{C}$ NMR (126 MHz, $\left.\mathrm{CD}_{3} \mathrm{CN}, 25^{\circ} \mathrm{C}\right), \delta(\mathrm{ppm}): 178.27$ (s, Ar-C=O), 142.26 (s, Ar-C), 137.96 (s, $\mathrm{Ar}-\mathrm{C}_{3} \mathrm{H}$ ), 134.87 (s, $\mathrm{Ar}-\mathrm{C}$ ), 133.10 (s, $\left.\mathrm{Ar}-\mathrm{CH}\right), 131.02$ (s, $\left.\mathrm{Ar}-\mathrm{CH}\right), 130.50$ (s, $\mathrm{Ar}-\mathrm{CH}$ ), 127.41 (s, $\operatorname{Ar}-\mathrm{CH}), 123.15$ (s, Ar-C). MS (m/z): calcd, $417.9027[\mathrm{M}]^{+}$; found, 417.9023 $\left(\mathrm{FAB}^{+},[\mathrm{M}]^{+}\right)$. 


\section{General procedure for determining the $\mathrm{p} K_{\mathrm{a}}$ of compounds 1, 2, 3 and 8}

The $\mathrm{pK}_{\mathrm{a}}$ values for compounds $\mathbf{1 , 2 , 3}$, and $\mathbf{8}$ were determined via ${ }^{1} \mathrm{H}$ NMR spectroscopy and are the average of triplicate self-consistent trials, as has been described previously. The compound of interest was combined with an acid or base of known $\mathrm{pK}_{\mathrm{a}}$ and the equilibrium populations were determined via ${ }^{1} \mathrm{H}$ NMR spectroscopy. All compounds exhibit rapid proton exchange on the NMR time-scale, such that the chemical shift can be used to determine the mole fraction of the species in solution via the equation $\chi_{\mathrm{A}}=\left(\delta_{\mathrm{eq}}-\right.$ $\left.\delta_{A}\right) /\left(\delta_{A}-\delta_{B}\right)$, where $\chi_{A}$ is mole fraction of the acid, $\delta_{e}$ is the equilibrium chemical shift and $\delta_{\mathrm{A}}$ and $\delta_{\mathrm{B}}$ are the chemical shifts of the pure acid and the pure conjugate base, respectively. The value of $\chi_{\mathrm{A}}$ was determined using well-resolved ${ }^{1} \mathrm{H}$ NMR signals, with good agreement observed between the independent calculations. The value used to determine the equilibrium concentration was the average of the independent caluclations. Once the equilibrium concentrations were determined, the equilibrium constant between the compound of interest and the acid/base of known $\mathrm{pK}_{\mathrm{a}}$ was determined, and by using Hess's law the $\mathrm{pK}_{\mathrm{a}}$ of the Mo complex (or 8) was determined. The following acids/bases were used to determine the unknown $\mathrm{pK}_{\mathrm{a}}$ 's: 4-tert-butylphenol $\left(\mathrm{pK}_{\mathrm{a}}=27.45\right)$ for compound 1 and 8; [2,2,2]-diazobicyclooctane $\left(\mathrm{pK}_{\mathrm{a}}=18.60\right)$ for compound 3; 2nitroaniline $\left(\mathrm{pK}_{\mathrm{a}}=4.80\right)$ for compound 2. Representative ${ }^{1} \mathrm{H}$ NMR spectra of equilibrium mixtures used to calculate $\mathrm{pKa}$ 's are given in Figure $\mathbf{S 2 7}$.

\section{Reactions of 1, 2 and 8 with TEMPO and 11 with TEMPOH}

1 and TEMPO: Compound 1 (0.0295 g, $0.0437 \mathrm{mmol})$ and TEMPO (0.0147 g, 0.0941 $\mathrm{mmol})$ were combined in $\mathrm{CD}_{3} \mathrm{CN}(0.6 \mathrm{~mL})$ in a 1 dram vial and thoroughly mixed for 30 seconds until all of $\mathbf{1}$ had solubilized and the color had darkened from pale orange to redorange. The solution was then transferred to an NMR tube and the ${ }^{1} \mathrm{H}$ and ${ }^{31} \mathrm{P} \mathrm{NMR}$ spectra were recorded (Figure $\mathbf{S 2 3}$ ).

2 and TEMPO: Compound 2 (0.0225 g, $0.0238 \mathrm{mmol})$ and TEMPO (0.0082 g, 0.0525 $\mathrm{mmol})$ were combined in $\mathrm{CD}_{3} \mathrm{CN}(0.6 \mathrm{~mL})$ in a 1 dram vial and thoroughly mixed for 30 seconds until all of $\mathbf{2}$ had solubilized and the color had darkened from pale orange to redorange. The solution was then transferred to an NMR tube and the ${ }^{1} \mathrm{H}$ and ${ }^{31} \mathrm{P} \mathrm{NMR}$ spectra were recorded (Figure S24).

8 and TEMPO: Compound 8 (0.0412 g, $0.0981 \mathrm{mmol})$ and TEMPO (0.0299 g, 0.191 mmol) were combined in $\mathrm{CD}_{3} \mathrm{CN}(0.6 \mathrm{~mL})$ in a 1 dram vial and thoroughly mixed for 30 seconds until all of $\mathbf{8}$ had solubilized. No color change was observed. The solution was then transferred to an NMR tube and the ${ }^{1} \mathrm{H}$ and ${ }^{31} \mathrm{P}$ NMR spectra were recorded (Figure S25). 
11 and TEMPOH: Compound $11(0.0100 \mathrm{~g}, 0.0239 \mathrm{mmol})$ and TEMPOH $(0.0075 \mathrm{~g}$, $0.0477 \mathrm{mmol})$ were combined in $\mathrm{CD}_{3} \mathrm{CN}(0.6 \mathrm{~mL})$ in a 1 dram vial and thoroughly mixed for 30 seconds until all of $\mathbf{1 1}$ had solubilized. The solution was then transferred to an NMR tube and the ${ }^{1} \mathrm{H}$ and ${ }^{31} \mathrm{P}$ NMR spectra were recorded, showing generation of compound $\mathbf{8}$ (Figure S26). The solution turned from a red orange to a pale pink within minutes. 


\section{Nuclear Magnetic Resonance Spectra}

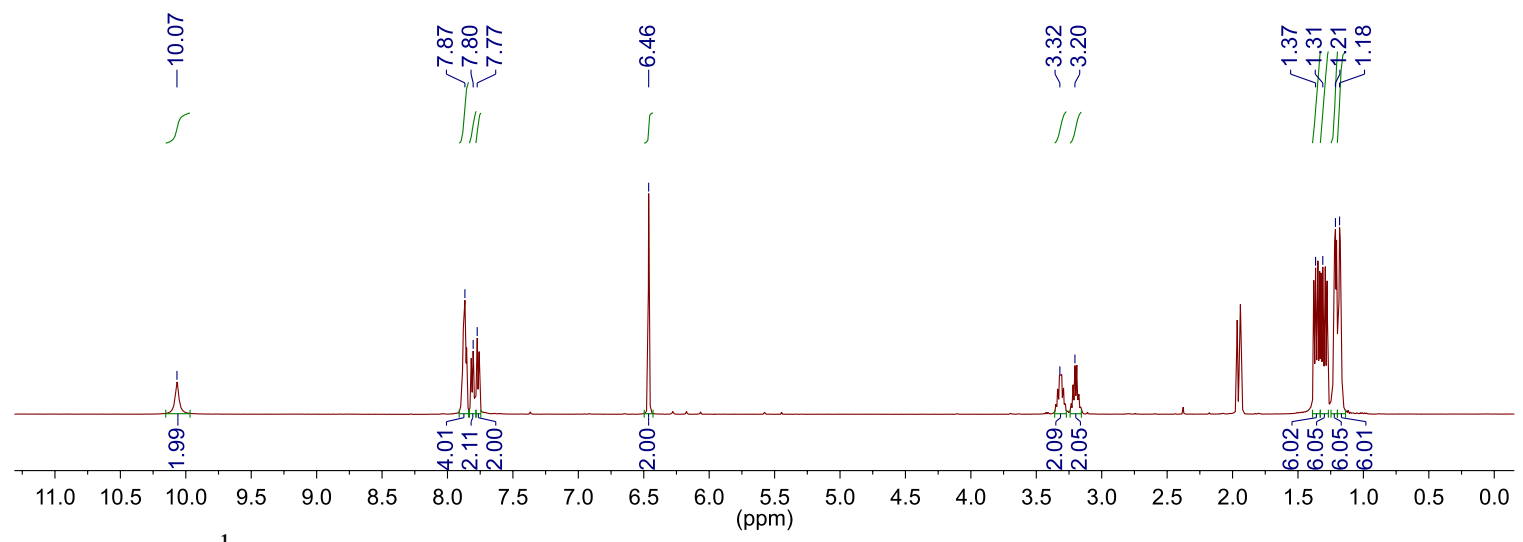

Figure S1. ${ }^{1} \mathrm{H}$ NMR spectrum of 2 in $\mathrm{CD}_{3} \mathrm{CN}$ at $25^{\circ} \mathrm{C}$.

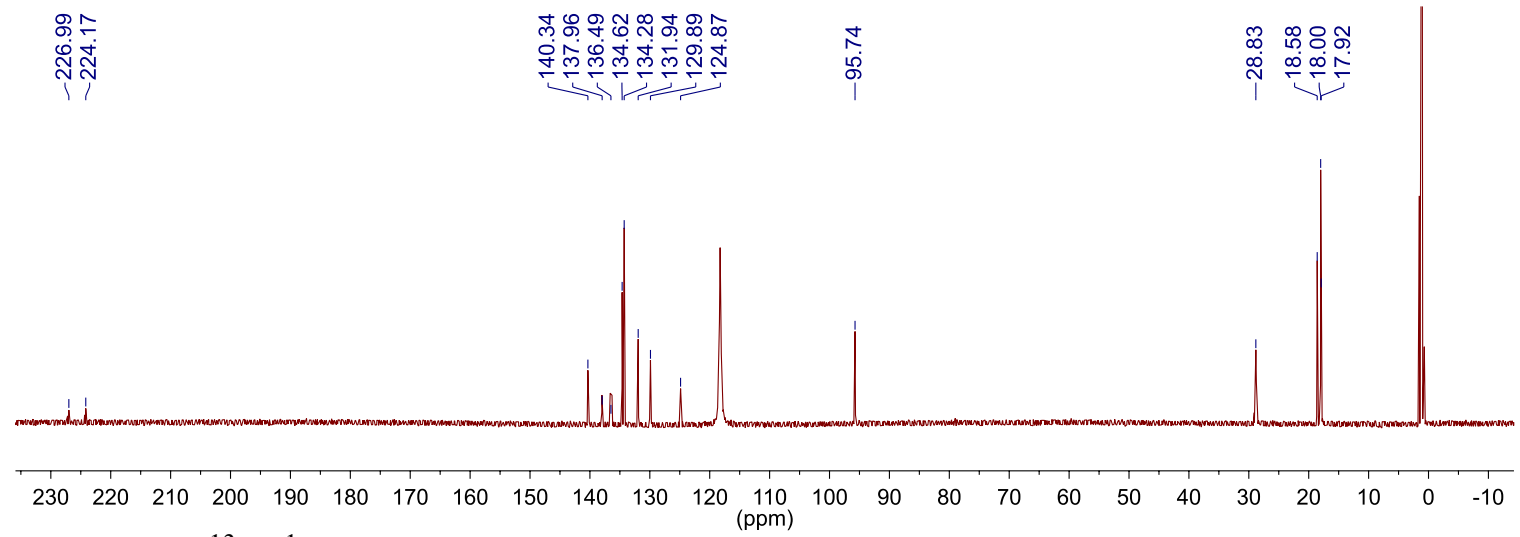

Figure S2. ${ }^{13} \mathrm{C}\left\{{ }^{1} \mathrm{H}\right\}$ NMR spectrum of 2 in $\mathrm{CD}_{3} \mathrm{CN}$ at $25{ }^{\circ} \mathrm{C}$.

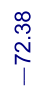

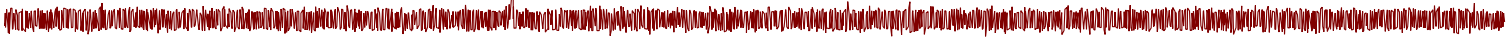
$\begin{array}{llllllllllllllllllllllllllllllllll}115 & 110 & 105 & 100 & 95 & 90 & 85 & 80 & 75 & 70 & 65 & 60 & 55 & 50 & 45 & 40 & 35 & 30 & 25 & 20 & 15 & 10 & 5 & 0 & -5 & -10\end{array}$ Figure S3. ${ }^{31} \mathrm{P}\left\{{ }^{1} \mathrm{H}\right\}$ NMR spectrum of 2 in $\mathrm{CD}_{3} \mathrm{CN}$ at $25^{\circ} \mathrm{C}$. 


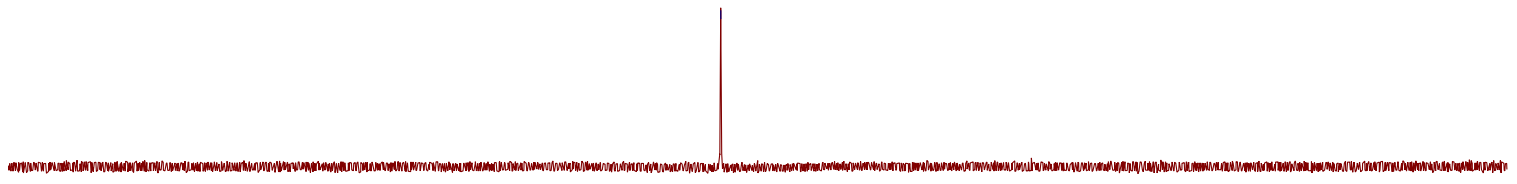

\begin{tabular}{llllllllllllllllllllllllll}
\hline 0 & 20 & 10 & 0 & -10 & -20 & -30 & -40 & -50 & -60 & -70 & -80 & -90 & -100 & -110 & -120 & -130 & -140 & -150 & -160 & -170 & -180 & -190 & -2(
\end{tabular} Figure S4. ${ }^{19} \mathrm{~F}$ NMR spectrum of 2 in $\mathrm{CD}_{3} \mathrm{CN}$ at $25^{\circ} \mathrm{C}$.

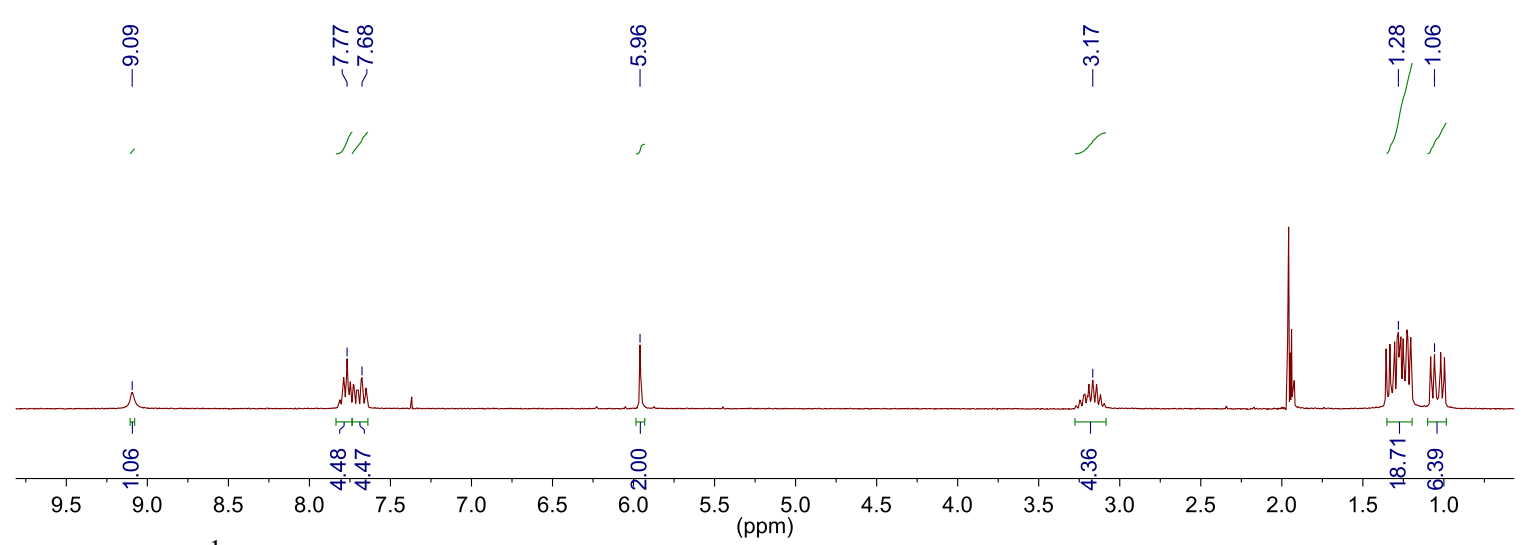

Figure S5. ${ }^{1} \mathrm{H}$ NMR spectrum of 3 in $\mathrm{CD}_{3} \mathrm{CN}$ at $25^{\circ} \mathrm{C}$.

$\begin{array}{ll}\infty & \bar{N} \\ \stackrel{0}{0} & \stackrel{N}{N} \\ \text { N } & \text { N }\end{array}$
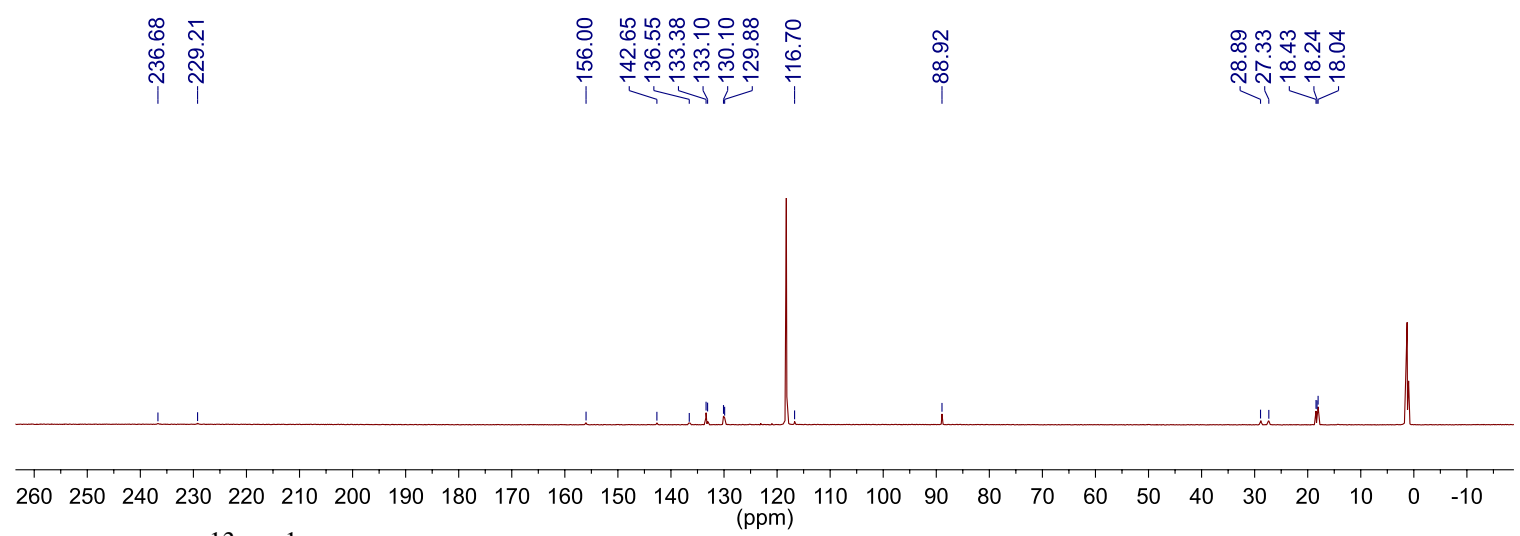

Figure S6. ${ }^{13} \mathrm{C}\left\{{ }^{1} \mathrm{H}\right\}$ NMR spectrum of 3 in $\mathrm{CD}_{3} \mathrm{CN}$ at $25{ }^{\circ} \mathrm{C}$. 


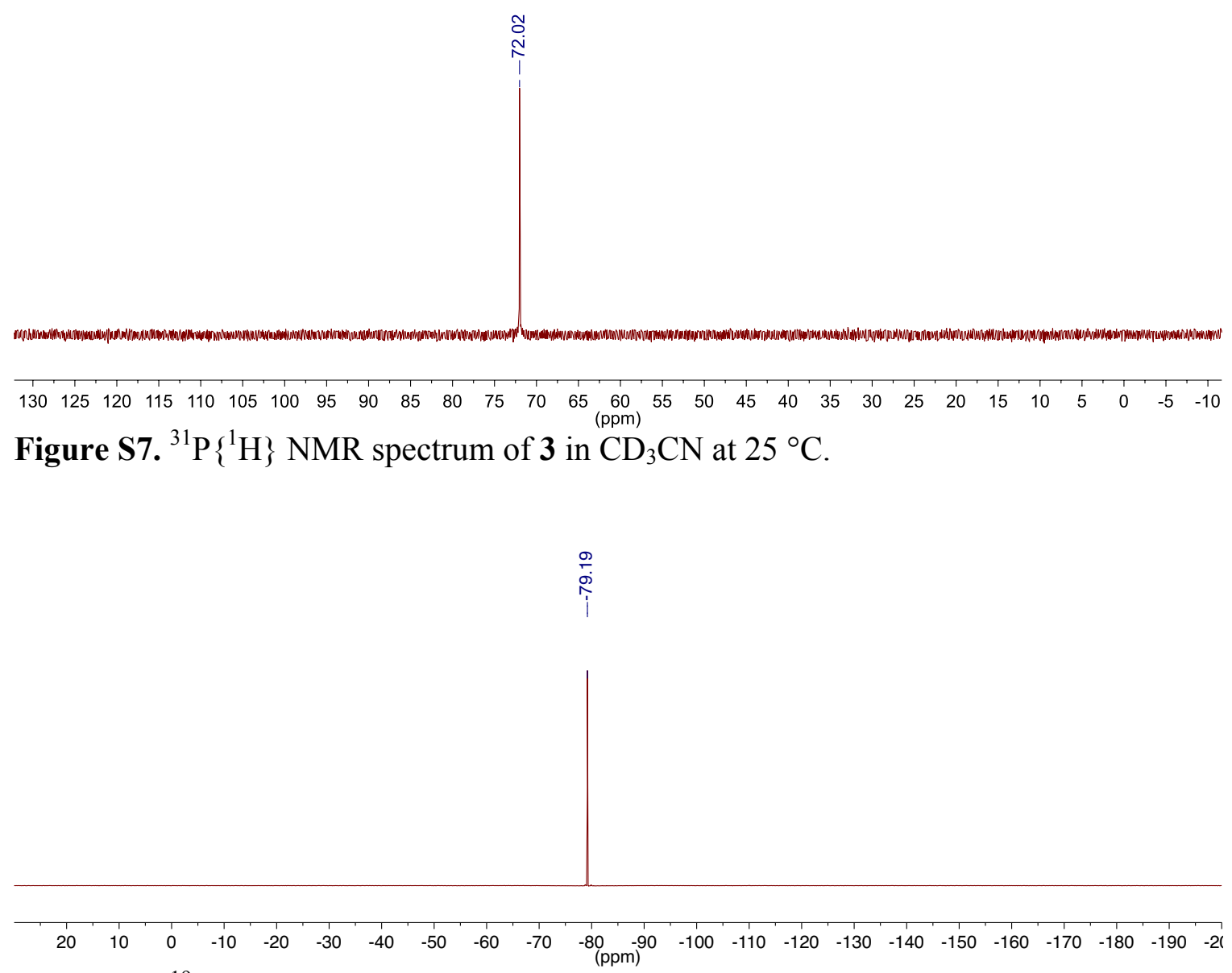

Figure S8. ${ }^{19} \mathrm{~F}$ NMR spectrum of 3 in $\mathrm{CD}_{3} \mathrm{CN}$ at $25^{\circ} \mathrm{C}$.

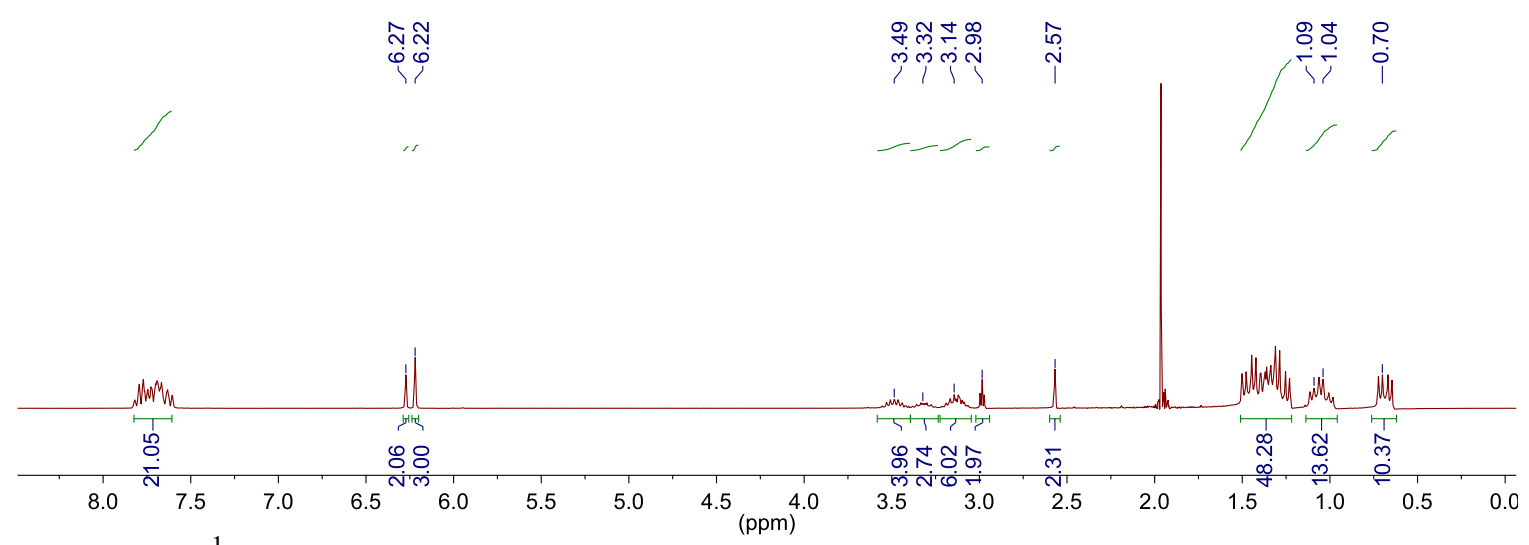

Figure S9. ${ }^{1} \mathrm{H}$ NMR spectrum of mixture of $\mathbf{5 a}$ and $\mathbf{5 b}$ in $\mathrm{CD}_{3} \mathrm{CN}$ at $25{ }^{\circ} \mathrm{C}$. 


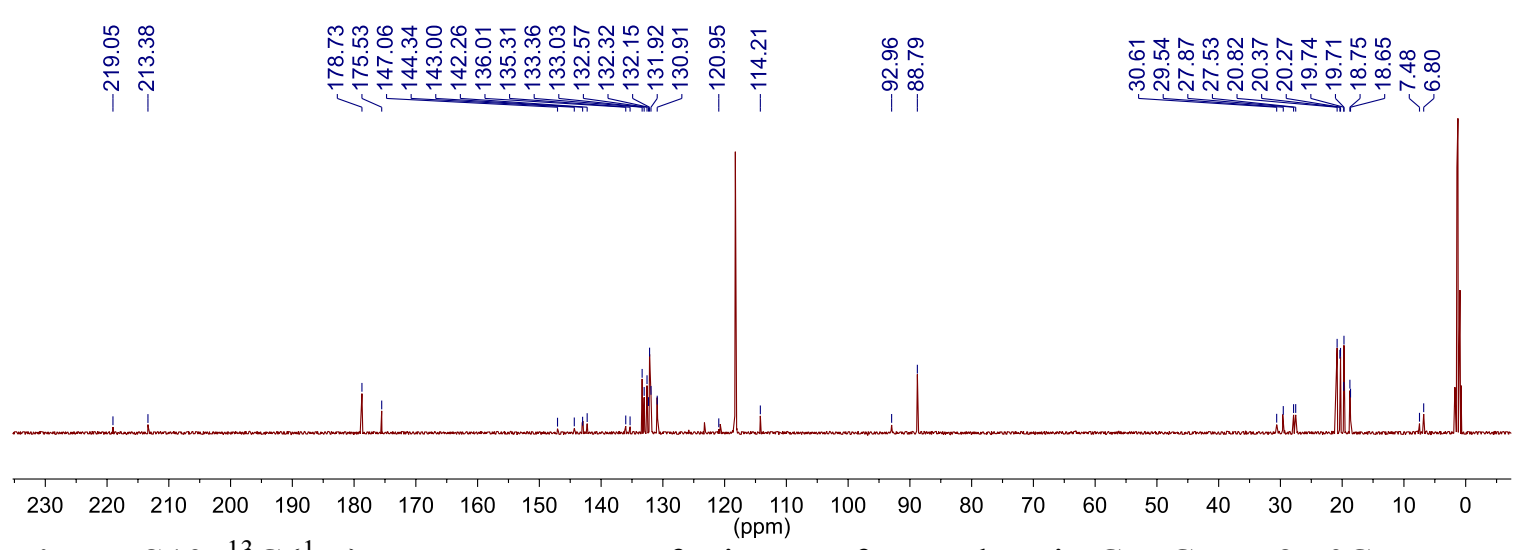

Figure S10. ${ }^{13} \mathrm{C}\left\{{ }^{1} \mathrm{H}\right\}$ NMR spectrum of mixture of $\mathbf{5 a}$ and $\mathbf{5 b}$ in $\mathrm{CD}_{3} \mathrm{CN}$ at $25{ }^{\circ} \mathrm{C}$.

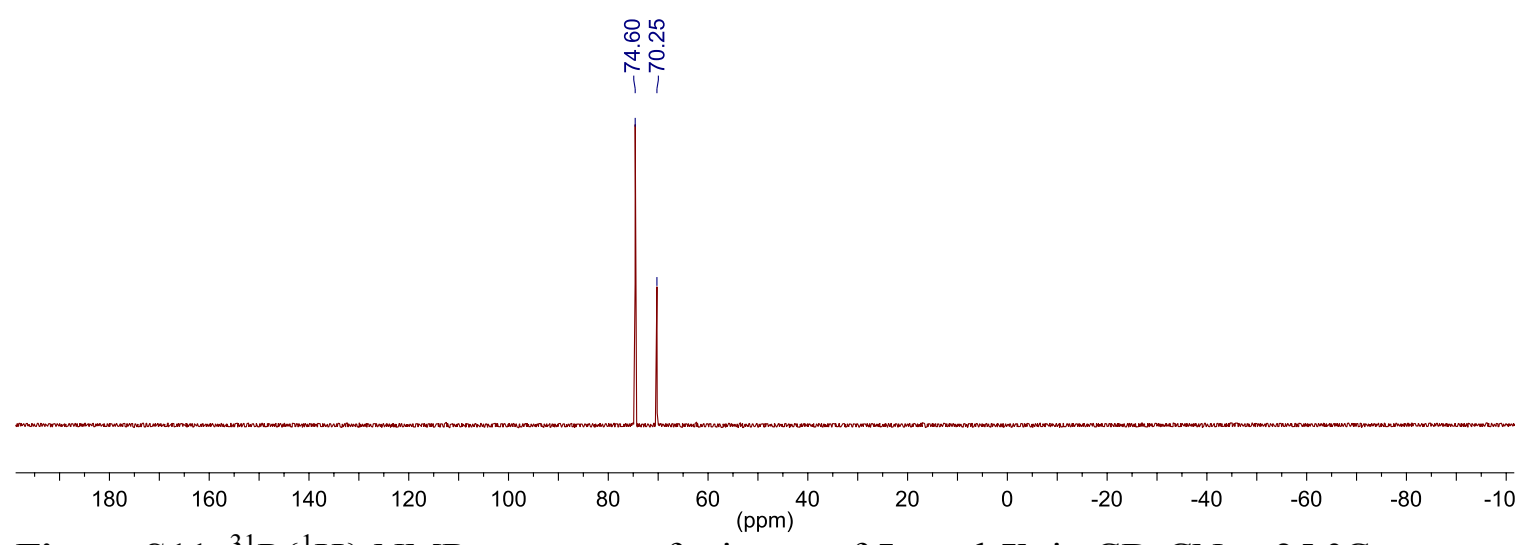

Figure S11. ${ }^{31} \mathrm{P}\left\{{ }^{1} \mathrm{H}\right\} \mathrm{NMR}$ spectrum of mixture of $\mathbf{5 a}$ and $\mathbf{5 b}$ in $\mathrm{CD}_{3} \mathrm{CN}$ at $25^{\circ} \mathrm{C}$.

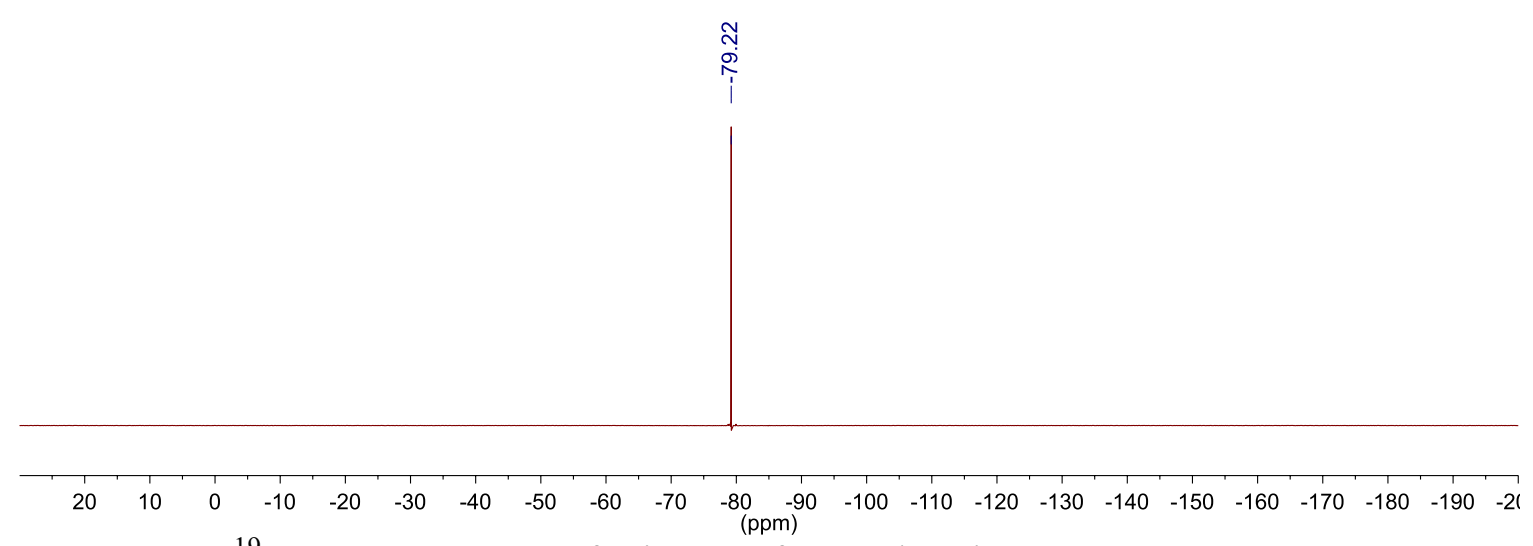

Figure S12. ${ }^{19} \mathrm{~F}$ NMR spectrum of mixture of $\mathbf{5 a}$ and $\mathbf{5 b}$ in $\mathrm{CD}_{3} \mathrm{CN}$ at $25{ }^{\circ} \mathrm{C}$. 


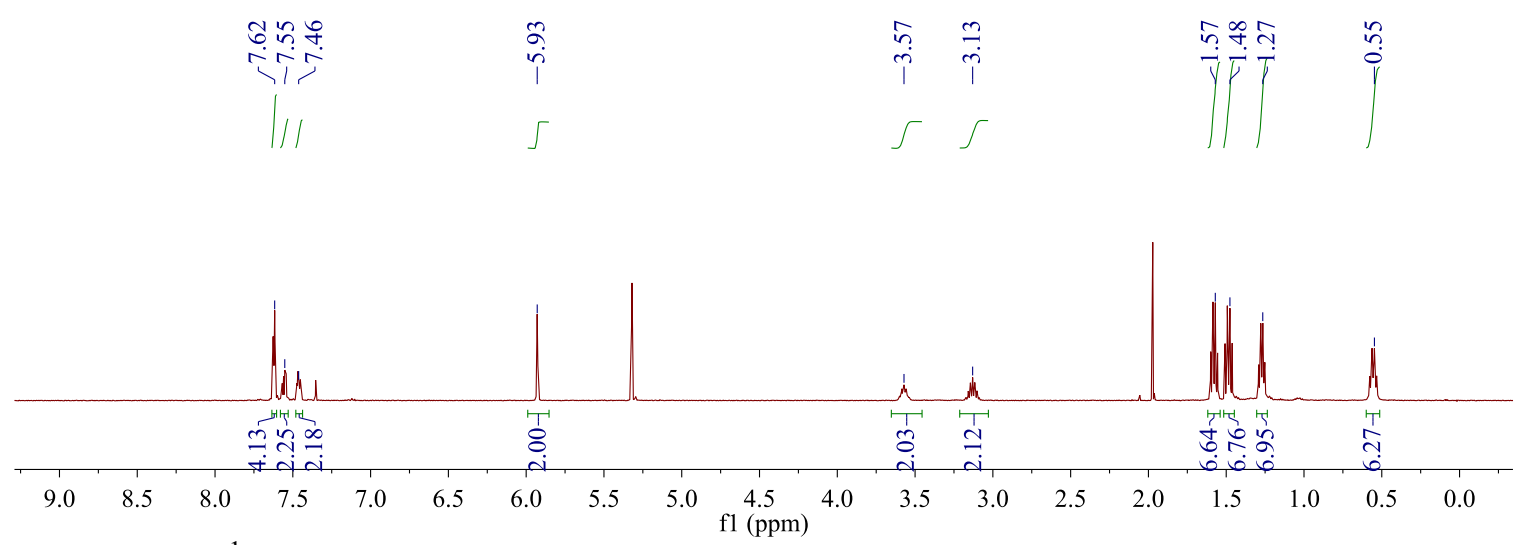

Figure S13. ${ }^{1} \mathrm{H}$ NMR spectrum of 6 in $\mathrm{CD}_{2} \mathrm{Cl}_{2}$ at $25^{\circ} \mathrm{C}$.

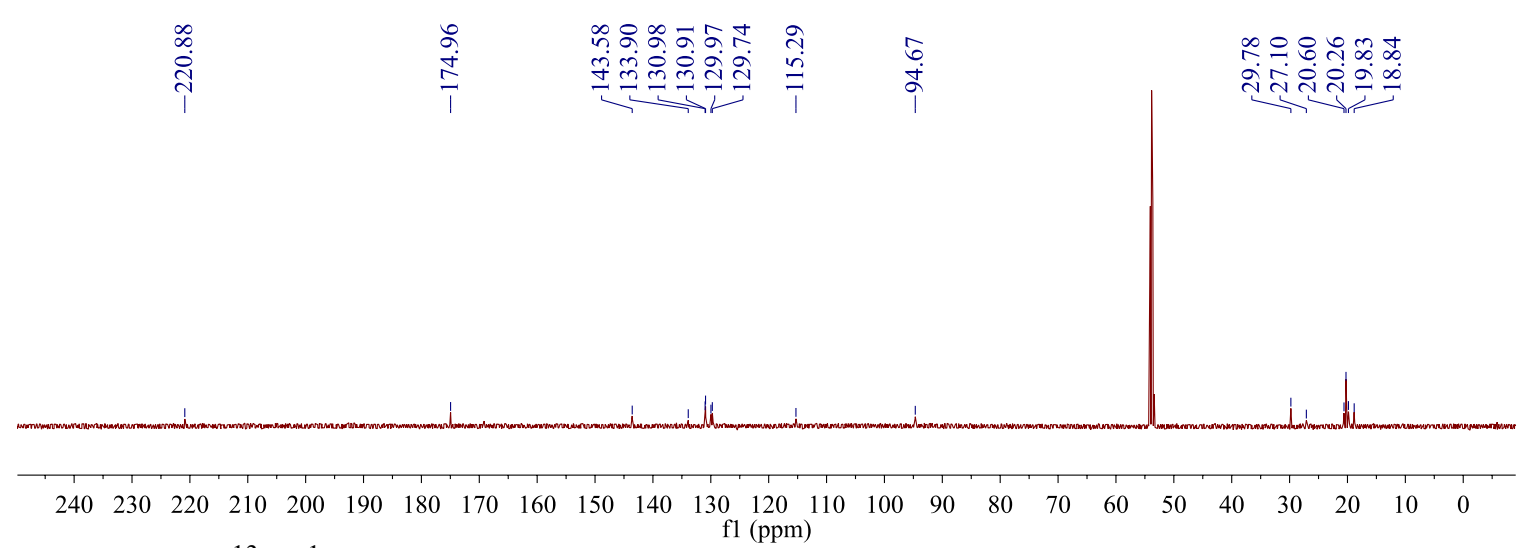

Figure S14. ${ }^{13} \mathrm{C}\left\{{ }^{1} \mathrm{H}\right\}$ NMR spectrum of 6 in $\mathrm{CD}_{2} \mathrm{Cl}_{2}$ at $25{ }^{\circ} \mathrm{C}$.

$\begin{array}{rlllllllllllllllllllllll}30 & 190 & 180 & 170 & 160 & 150 & 140 & 130 & 120 & 110 & 100 & 90 & \begin{array}{r}80 \\ \mathrm{fl}(\mathrm{ppm})\end{array} & 60 & 50 & 40 & 30 & 20 & 10 & 0 & -10 & -20 & -30 & -40\end{array}$

Figure S15. ${ }^{31} \mathrm{P}\left\{{ }^{1} \mathrm{H}\right\}$ NMR spectrum of 6 in $\mathrm{CD}_{2} \mathrm{Cl}_{2}$ at $25{ }^{\circ} \mathrm{C}$. 


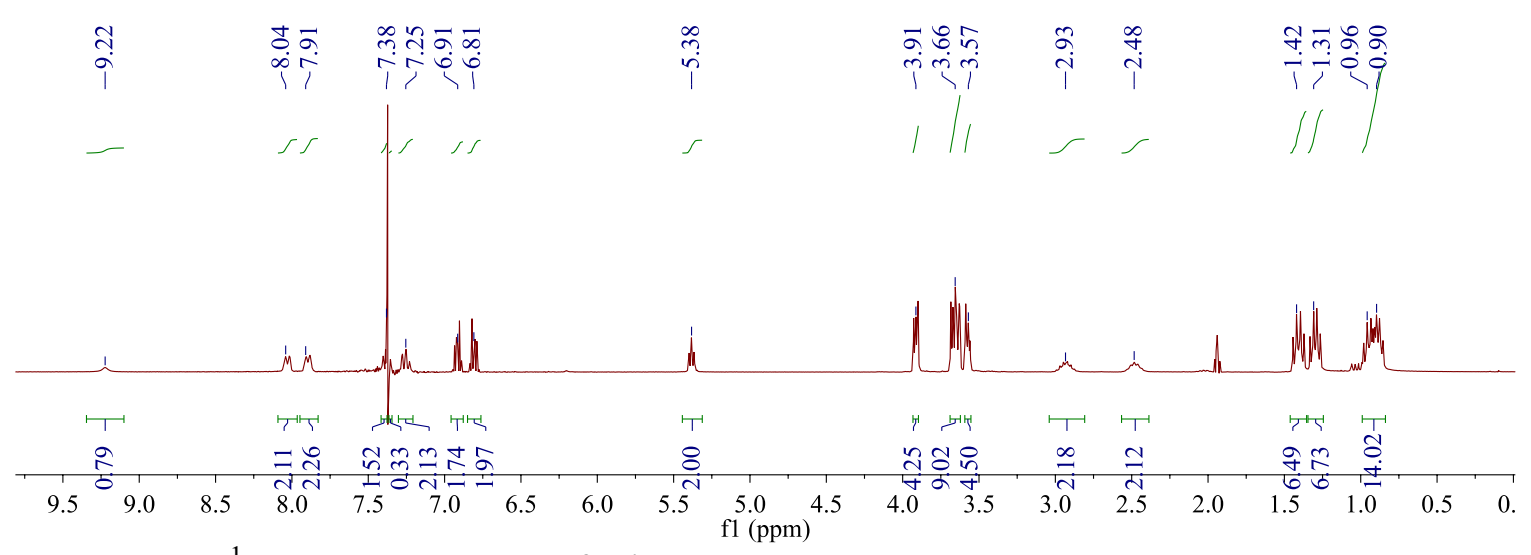

Figure S16. ${ }^{1} \mathrm{H}$ NMR spectrum of 9 in $\mathrm{CD}_{3} \mathrm{CN}$ at $25^{\circ} \mathrm{C}$.
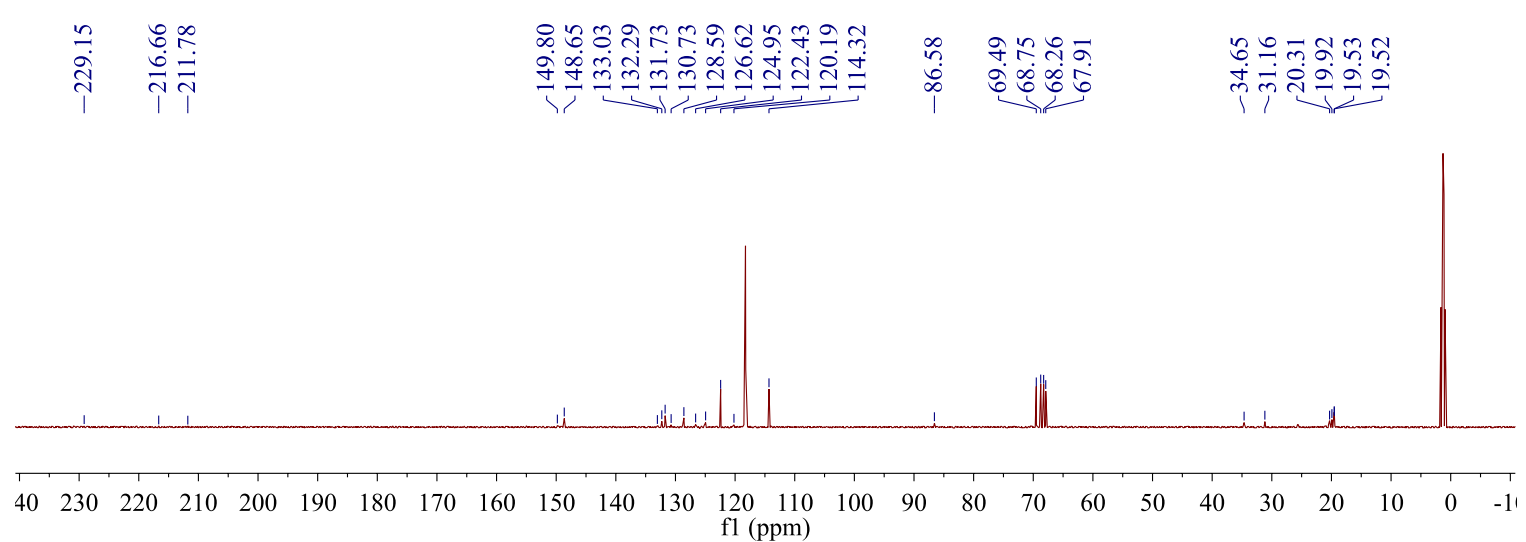

Figure S17. ${ }^{13} \mathrm{C}\left\{{ }^{1} \mathrm{H}\right\}$ NMR spectrum of 9 in $\mathrm{CD}_{3} \mathrm{CN}$ at $25{ }^{\circ} \mathrm{C}$.

$$
\frac{\stackrel{+}{\mathfrak{n}}}{i}
$$

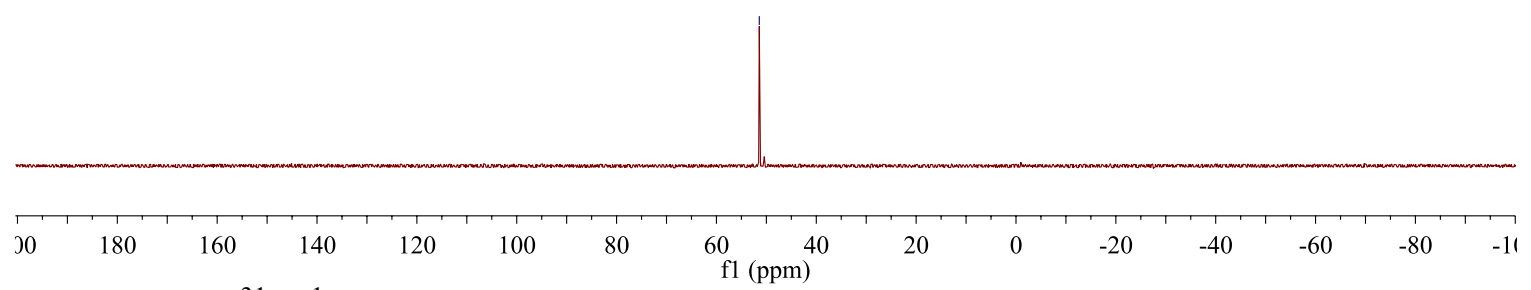

Figure S18. ${ }^{31} \mathrm{P}\left\{{ }^{1} \mathrm{H}\right\}$ NMR spectrum of 9 in $\mathrm{CD}_{3} \mathrm{CN}$ at $25^{\circ} \mathrm{C}$. 


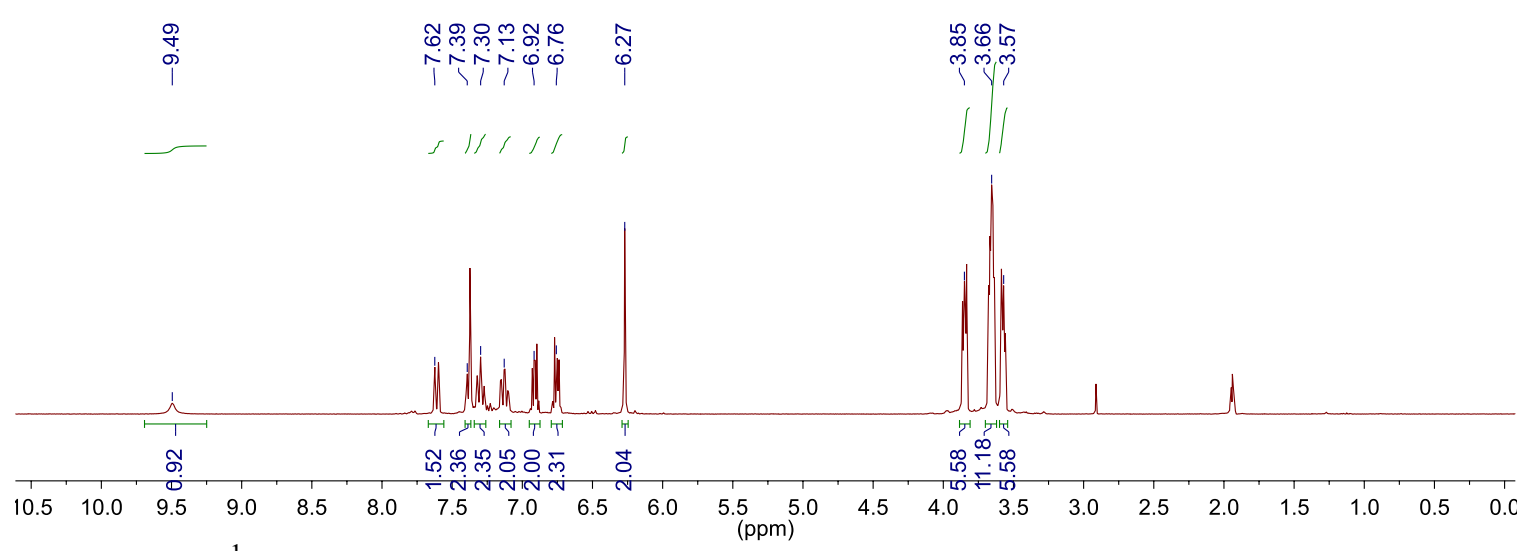

Figure S19. ${ }^{1} \mathrm{H}$ NMR spectrum of 10 in $\mathrm{CD}_{3} \mathrm{CN}$ at $25^{\circ} \mathrm{C}$.

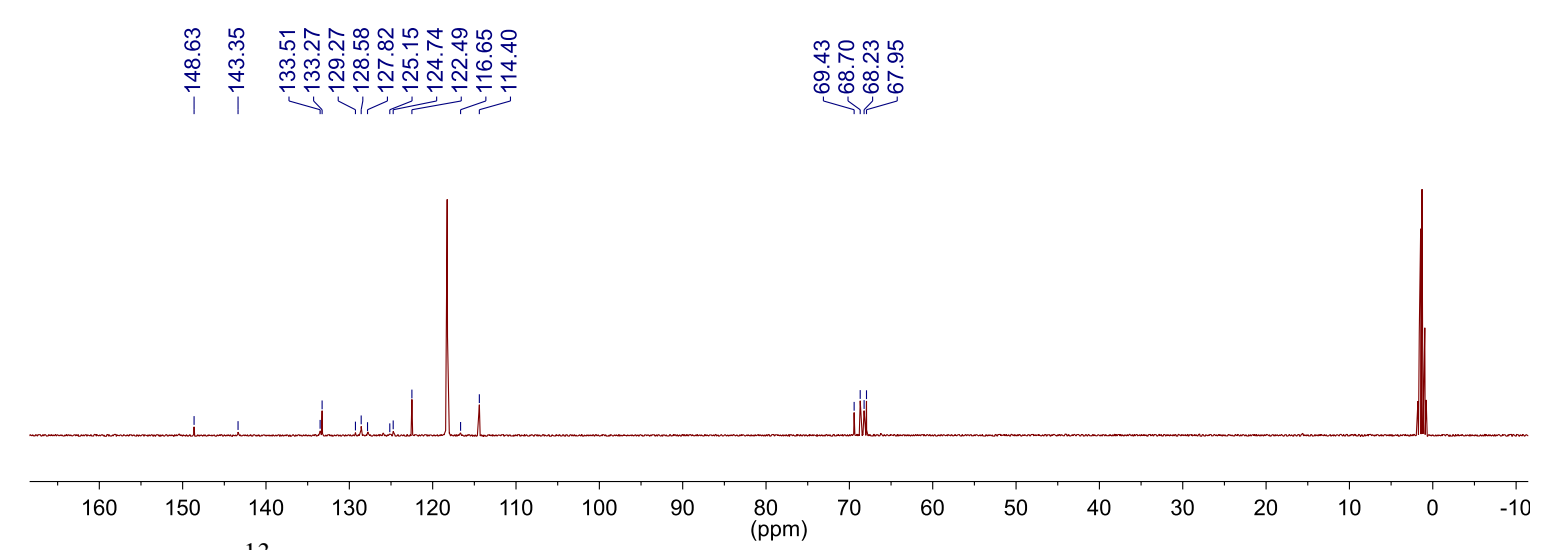

Figure S20. ${ }^{13} \mathrm{C}$ NMR spectrum of $\mathbf{1 0}$ in $\mathrm{CD}_{3} \mathrm{CN}$ at $25{ }^{\circ} \mathrm{C}$.

ิิ $\stackrel{\circ}{m} \stackrel{\infty}{\sim} \stackrel{m}{\sim}$
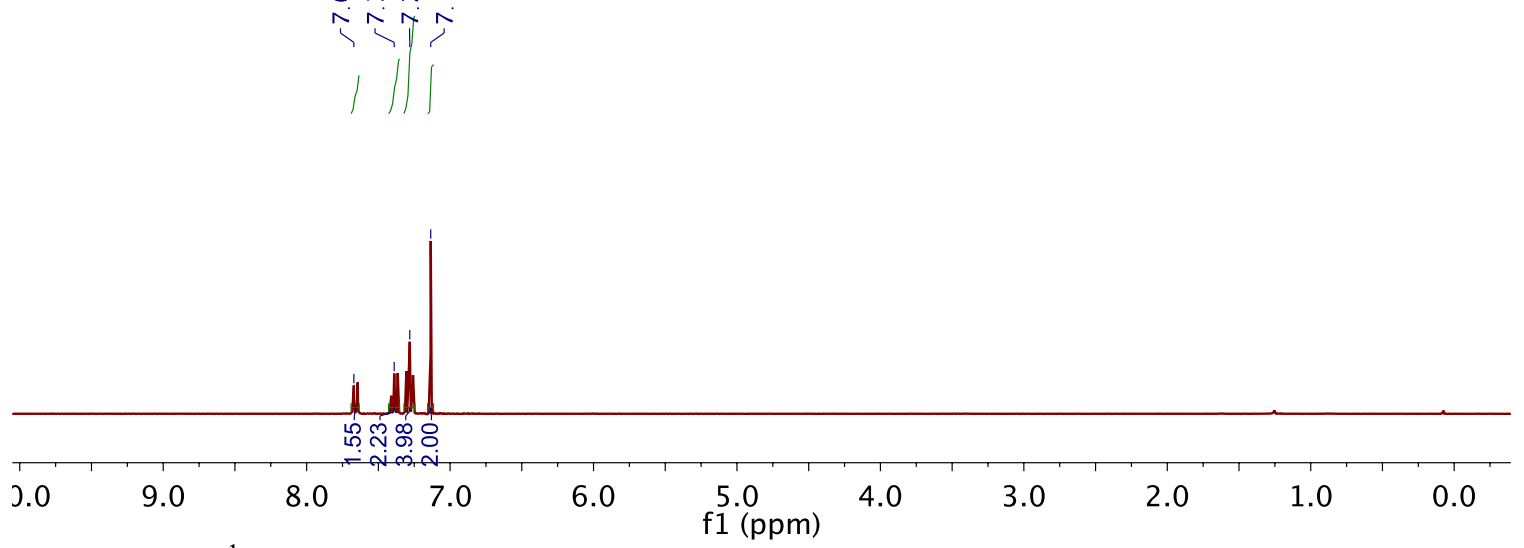

Figure S21. ${ }^{1} \mathrm{H}$ NMR spectrum of $\mathbf{1 1}$ in $\mathrm{CDCl}_{3}$ at $25^{\circ} \mathrm{C}$. 


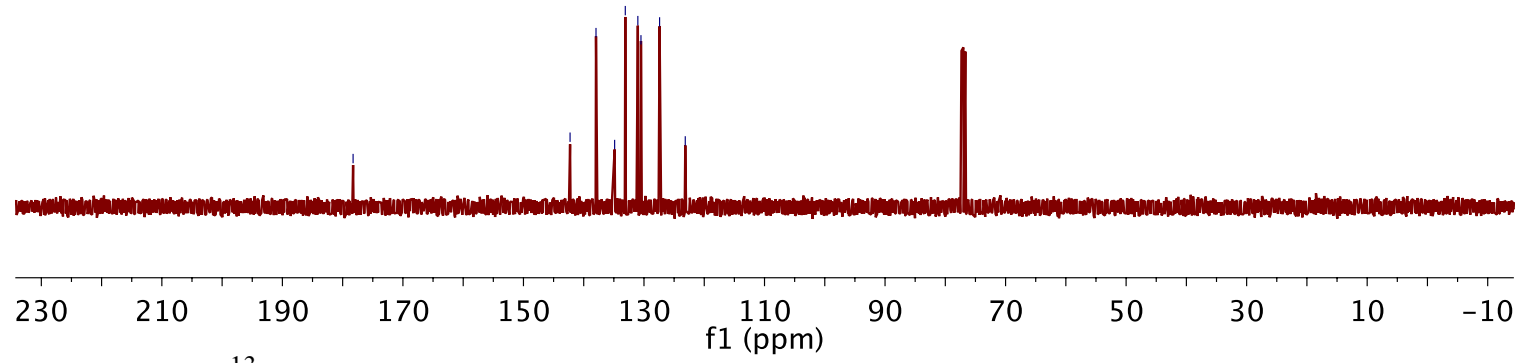

Figure S22. ${ }^{13} \mathrm{C}$ NMR spectrum of 11 in $\mathrm{CDCl}_{3}$ at $25{ }^{\circ} \mathrm{C}$.

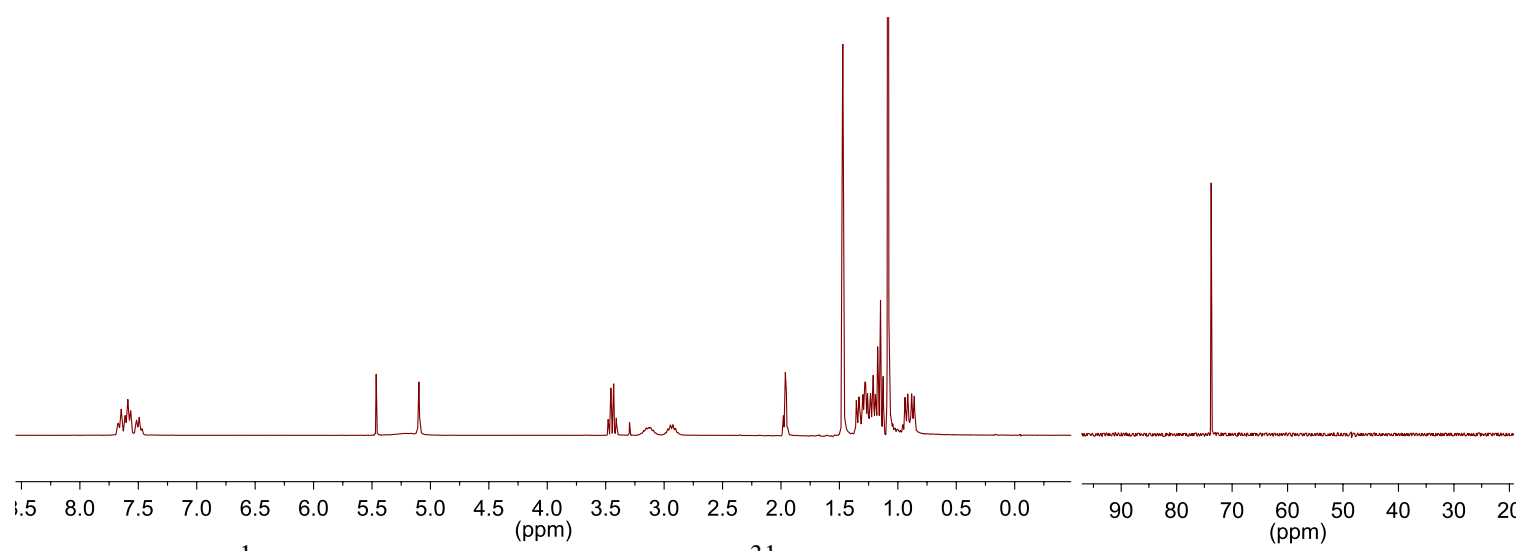

Figure S23. ${ }^{1} \mathrm{H}$ NMR spectrum (left) and ${ }^{31} \mathrm{P}$ NMR spectrum (right) of 1 and 2 equiv. TEMPO in $\mathrm{CD}_{3} \mathrm{CN}$ at $25^{\circ} \mathrm{C}$ after $10 \mathrm{~min}$.

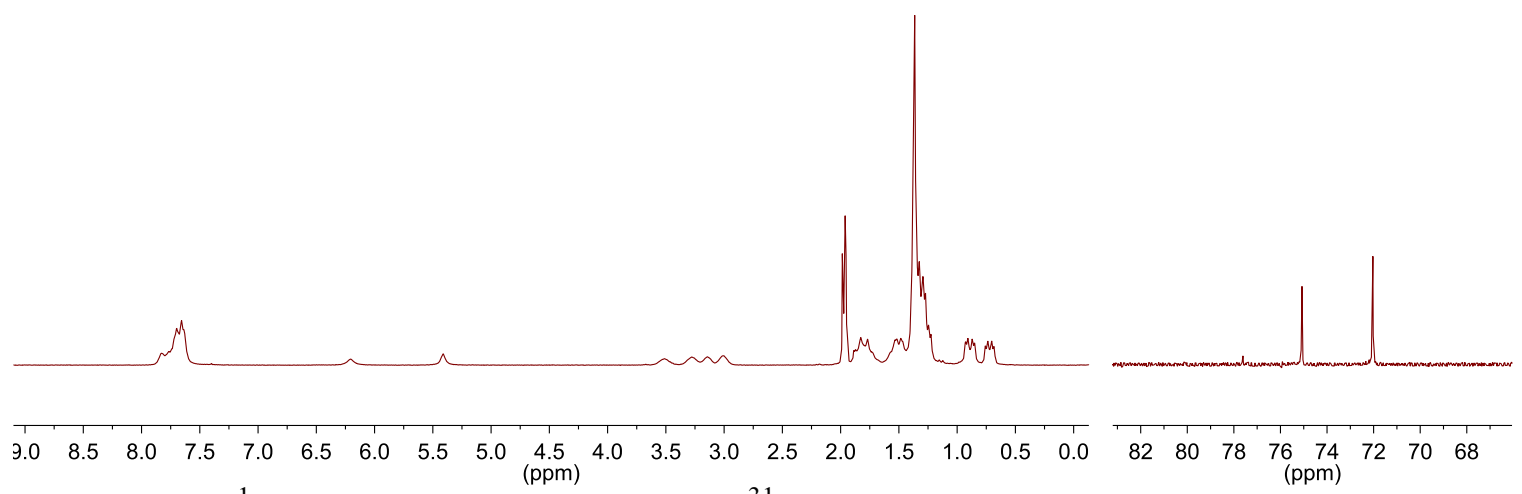

Figure S24. ${ }^{1} \mathrm{H}$ NMR spectrum (left) and ${ }^{31} \mathrm{P}$ NMR spectrum (right) of 2 and 2 equiv. TEMPO in $\mathrm{CD}_{3} \mathrm{CN}$ at $25^{\circ} \mathrm{C}$ after $10 \mathrm{~min}$. 


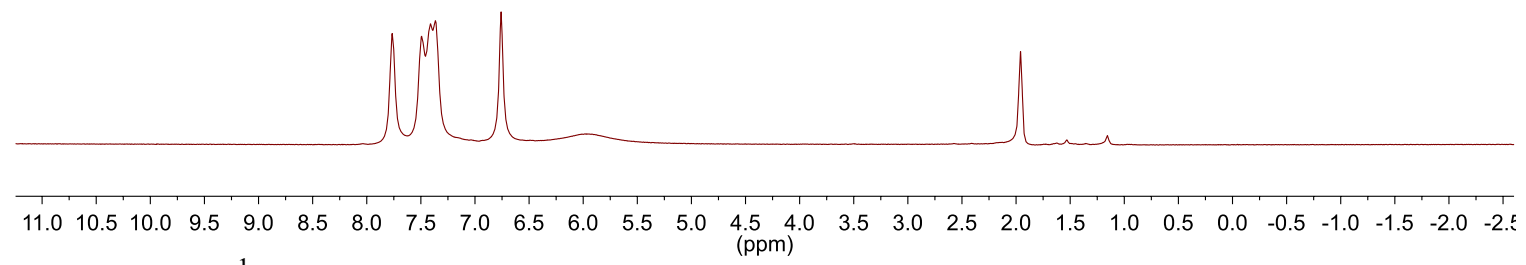

Figure S25. ${ }^{1} \mathrm{H}$ NMR spectrum of 8 and 2 equiv. TEMPO in $\mathrm{CD}_{3} \mathrm{CN}$ at $25{ }^{\circ} \mathrm{C}$ after 10 $\min$.

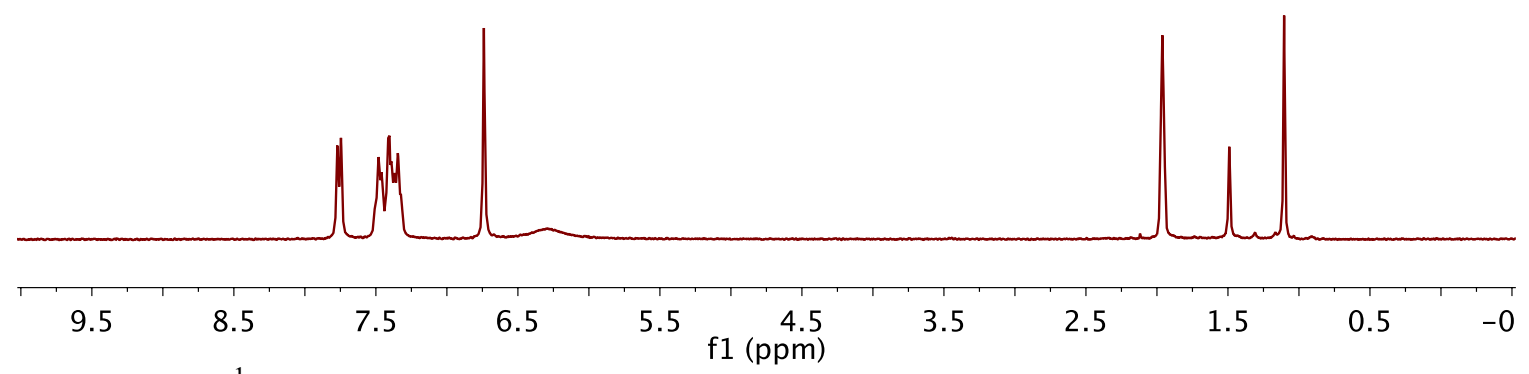

Figure S26. ${ }^{1} \mathrm{H}$ NMR spectrum of 11 and 2 equiv. TEMPOH in $\mathrm{CD}_{3} \mathrm{CN}$ at $25{ }^{\circ} \mathrm{C}$ after 10 $\min$.

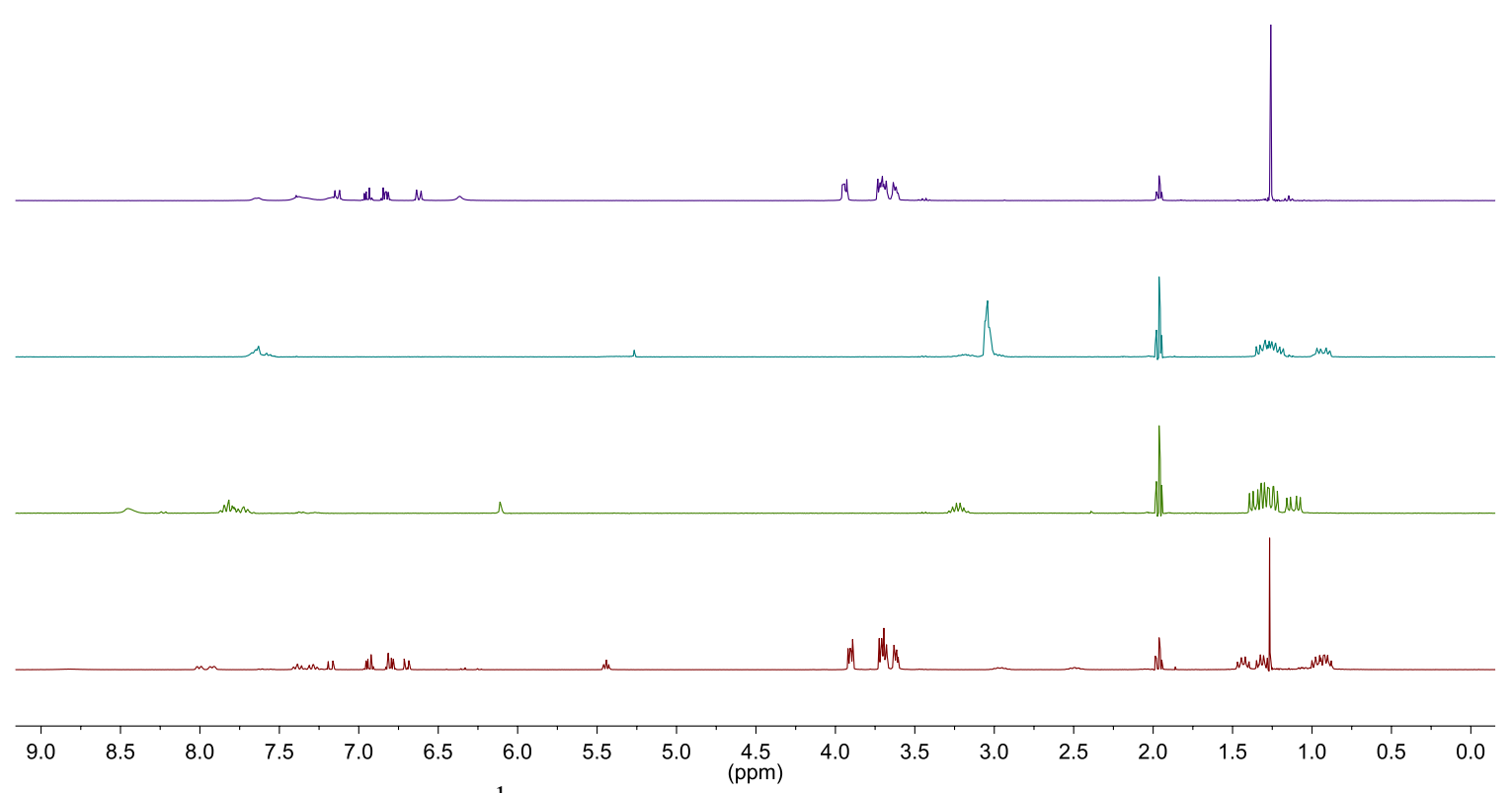

Figure S27. Representative ${ }^{1} \mathrm{H}$ NMR spectrum of equilibrium mixtures in $\mathrm{CD}_{3} \mathrm{CN}$ of 9 and $4-{ }^{t} \mathrm{BuPhOH}$ (brown), 2 and $2-\mathrm{NO}_{2} \mathrm{PhNH}_{2}$ (green), 3 and DABCO (teal), and $\mathbf{1 0}$ and 4- ${ }^{t} \mathrm{BuPhOH}$ (purple) all recorded at $25^{\circ} \mathrm{C}$. 


\section{Estimation of $O-H B D F E$}

Table S1. Thermochemical data for selected quinonoid compounds. Note that 1, 2, and $\mathbf{3}$ show irreversible redox events by cyclic voltammetry.

\begin{tabular}{cccc}
\hline & $\mathrm{pK}_{\mathrm{a}(\mathrm{O}-\mathrm{H})}{ }^{\mathrm{a}}$ & $\mathrm{E}^{\circ}{ }_{\operatorname{Irr}\left(\mathrm{O}^{-} / \mathrm{O} \cdot\right)^{\mathrm{b}}}$ & Estimated BDFE $\mathrm{O}^{-\mathrm{H}}{ }^{\mathrm{c}}$ \\
\hline $\mathbf{1}$ & $25.89(9)$ & $-0.770 \mathrm{~V}$ & $73 \mathrm{kcal} / \mathrm{mol}$ \\
$\mathbf{2}$ & $4.74(9)$ & $0.220 \mathrm{~V}$ & $67 \mathrm{kcal} / \mathrm{mol}$ \\
$\mathbf{3}$ & $17.1(4)$ & $-0.470 \mathrm{~V}$ & $68 \mathrm{kcal} / \mathrm{mol}$ \\
$\mathbf{8}$ & $26.3(1)$ & $-0.630 \mathrm{~V}^{\mathrm{d}}$ & $76 \mathrm{kcal} / \mathrm{mol}$ \\
\hline
\end{tabular}

${ }^{\mathrm{a}} \mathrm{pK}_{\mathrm{a}}$ for first $\mathrm{O}-\mathrm{H}$ determined via solution equilibria (see SI). ${ }^{\mathrm{b}}$ Irreversible oxidation potential for conjugate base determined via square-wave voltammetry. ${ }^{\circ}$ Calculated using equation (1). ${ }^{\mathrm{a}}$ Reversible oxidation event.

\section{Crystallographic Information}

CCDC 1469761-1469764 contain the supplementary crystallographic data for this paper. These data can be obtained free of charge from The Cambridge Crystallographic Data Centre via www.ccdc.cam.ac.uk/data_request/cif.

\section{Refinement Details}

In each case, crystals were mounted on a glass fiber or nylon loop using Paratone oil, then placed on the diffractometer under a nitrogen stream. Low temperature $(100 \mathrm{~K}) \mathrm{X}$ ray data were obtained on a Bruker APEXII CCD based diffractometer (Mo sealed X-ray tube, $\mathrm{K}_{\alpha}=0.71073 \AA$ ) or a Bruker PHOTON100 CMOS based diffractometer (Mo microfocus sealed X-ray tube, $\mathrm{K}_{\alpha}=0.71073 \AA$ ). All diffractometer manipulations, including data collection, integration, and scaling were carried out using the Bruker APEXII software. $^{6}$ Absorption corrections were applied using SADABS. ${ }^{7}$ Space groups were determined on the basis of systematic absences and intensity statistics and the structures were solved by direct methods using $\mathrm{XS}^{8}$, by intrinsic phasing using XT (incorporated into SHELXTL), or by charge flipping using Olex $2^{9}$ and refined by full-matrix least squares on $\mathrm{F}^{2}$. All non-hydrogen atoms were refined using anisotropic displacement parameters. Hydrogen atoms were placed in the idealized positions and refined using a riding model. The structures were refined (weighed least squares refinement on $\mathrm{F}^{2}$ ) to convergence. Graphical representation of structures with 50\% probability thermal ellipsoids was generated using Diamond visualization software. ${ }^{10}$ 
Table S2. Crystal and refinement data for $3,5 a \cdot 2 N C M e, ~ 5 b$, and 6 .

\begin{tabular}{|c|c|c|c|c|}
\hline Compound & 3 & $5 \mathrm{a} \cdot 2 \mathrm{NCMe}$ & $\mathbf{5 b}$ & 6 \\
\hline CCDC & 1469761 & 1469762 & 1469763 & 1469764 \\
\hline empirical formula & $\mathrm{C}_{33} \mathrm{H}_{39} \mathrm{~F}_{3} \mathrm{MoO}_{7} \mathrm{P}_{2} \mathrm{~S}$ & $\mathrm{C}_{39} \mathrm{H}_{50} \mathrm{~F}_{12} \mathrm{MoN}_{4} \mathrm{O}_{3} \mathrm{P}_{2} \mathrm{Sb}_{2}$ & $\mathrm{C}_{37} \mathrm{H}_{44} \mathrm{~F}_{6} \mathrm{MoN}_{2} \mathrm{O}_{9} \mathrm{P}_{2} \mathrm{~S}_{2}$ & $\mathrm{C}_{31} \mathrm{H}_{38} \mathrm{Cl}_{2} \mathrm{MoO}_{3} \mathrm{P}_{2}$ \\
\hline formula wt & $794.61 \mathrm{~g} / \mathrm{mol}$ & $1252.23 \mathrm{~g} / \mathrm{mol}$ & $996.74 \mathrm{~g} / \mathrm{mol}$ & $687.39 \mathrm{~g} / \mathrm{mol}$ \\
\hline $\mathrm{T}(\mathrm{K})$ & 100 & 100 & 100 & 100 \\
\hline $\mathrm{a}, \AA$ & $30.285(3)$ & $10.005(1)$ & $11.3464(4)$ & $16.255(1)$ \\
\hline $\mathrm{b}, \AA$ & $26.445(2)$ & $27.668(2)$ & $21.2519(8)$ & $16.255(1)$ \\
\hline $\mathrm{c}, \AA$ & $17.945(1)$ & $19.306(1)$ & $17.4117(7)$ & $22.205(2)$ \\
\hline$\alpha, \operatorname{deg}$ & 90 & 90 & 90 & 90 \\
\hline$\beta, \operatorname{deg}$ & $93.729(2)$ & $94.925(3)$ & $94.171(1)$ & 90 \\
\hline$\gamma, \operatorname{deg}$ & 90 & 90 & 90 & 90 \\
\hline $\mathrm{V}, \AA^{3}$ & $14341(2)$ & $5324.3(5)$ & $4187.4(3)$ & $5866.9(5)$ \\
\hline $\mathrm{Z}$ & 4 & 4 & 4 & 8 \\
\hline cryst syst & Monoclinic & Monoclinic & Monoclinic & Orthorhombic \\
\hline space group & $\mathrm{P} 2{ }_{1} / \mathrm{c}$ & $\mathrm{P} 21 / \mathrm{n}$ & $\mathrm{P} 2{ }_{1} / \mathrm{n}$ & Pbca \\
\hline $\mathrm{d}_{\text {calc }}, \mathrm{g} / \mathrm{cm}^{3}$ & 1.407 & 1.562 & 1.581 & 1.556 \\
\hline$\theta$ range, deg & $2.18-33.14$ & $1.29-38.57$ & $2.629-43.71$ & $1.83-45.29$ \\
\hline$\mu, \mathrm{mm}^{-1}$ & 0.573 & 1.377 & 0.571 & 0.771 \\
\hline abs cor & Semi-empirical & Semi-empirical & Semi-empirical & Semi-empirical \\
\hline GOF & 1.070 & 1.132 & 1.058 & 0.954 \\
\hline $\begin{array}{l}R_{1}^{a}, w R_{2}^{b}(\mathrm{I}> \\
2 \operatorname{sig}(\mathrm{I}))\end{array}$ & $0.0556,0.1313$ & $0.0409,0.1502$ & $0.0317,0.0756$ & $0.0338,0.0868$ \\
\hline Diffractometer & APEXII & APEXII & PHOTON100 & APEXII \\
\hline
\end{tabular}

${ }^{\mathrm{a}} \mathrm{R}_{1}=\Sigma|| \mathrm{F}_{\mathrm{o}}|-| \mathrm{F}_{\mathrm{c}}|| \Sigma\left|\mathrm{F}_{\mathrm{o}}\right|{ }^{\mathrm{b}} \mathrm{wR}_{2}=\left[\Sigma\left[\mathrm{w}\left(\mathrm{F}_{\mathrm{o}}{ }^{2}-\mathrm{F}_{\mathrm{c}}{ }^{2}\right)^{2}\right] / \Sigma\left[\mathrm{w}\left(\mathrm{F}_{\mathrm{o}}{ }^{2}\right)^{2}\right]\right]^{1 / 2}$ 


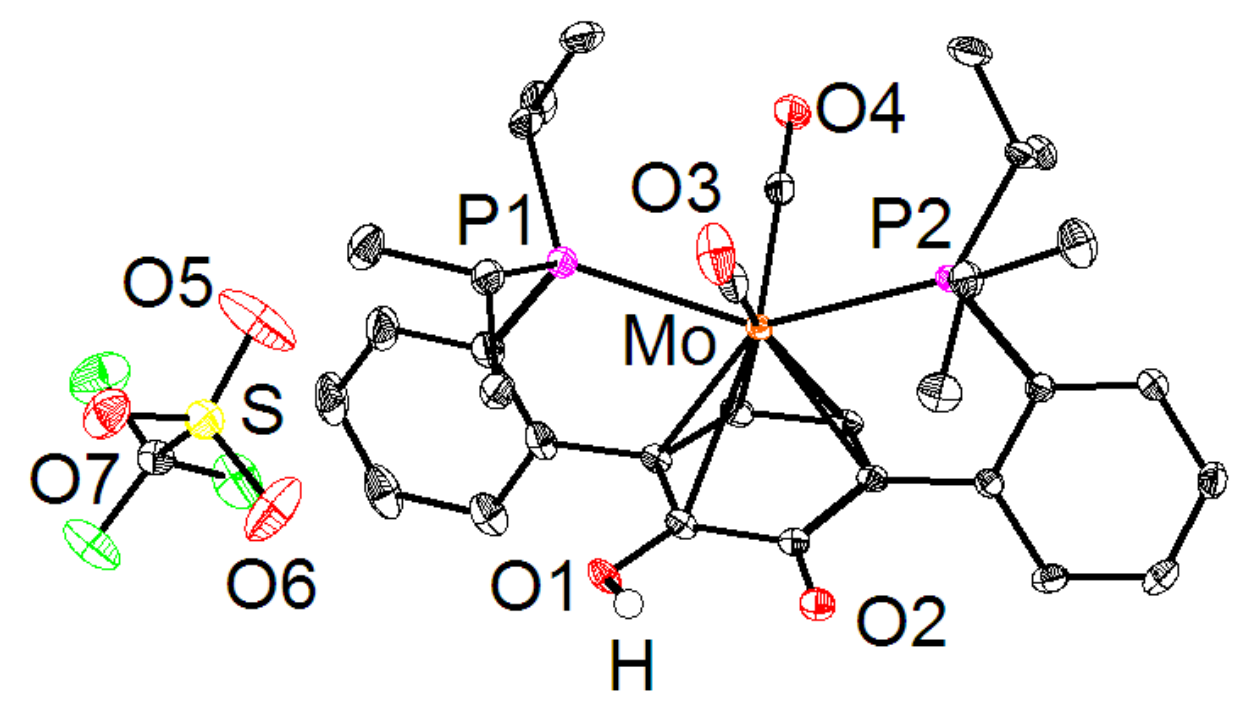

Figure S28. Structural drawing of $\mathbf{3}$ with $50 \%$ probability ellipsoids. Hydrogen atoms, and additional three Mo complexes and three triflate anions of the asymmetric unit are omitted for clarity. Carbon and fluorine atoms are shown in black and green, respectively.

Special Refinement Details for 3: One of the four triflate anions was positionally disordered and satisfactorily modeled as approximately a 50:50 mixture using "PART", "SAME", and "EADP" cards in SHELX. Two isopropyl groups were also positionally disordered and satisfactorily modeled as approximately 70:30 mixtures using "PART" cards in SHELX. Two DMF solvent molecules were highly disordered and could not be adequately modeled even with constraints. The electron density of these molecules was removed using the "solvent mask" function in Olex2. 


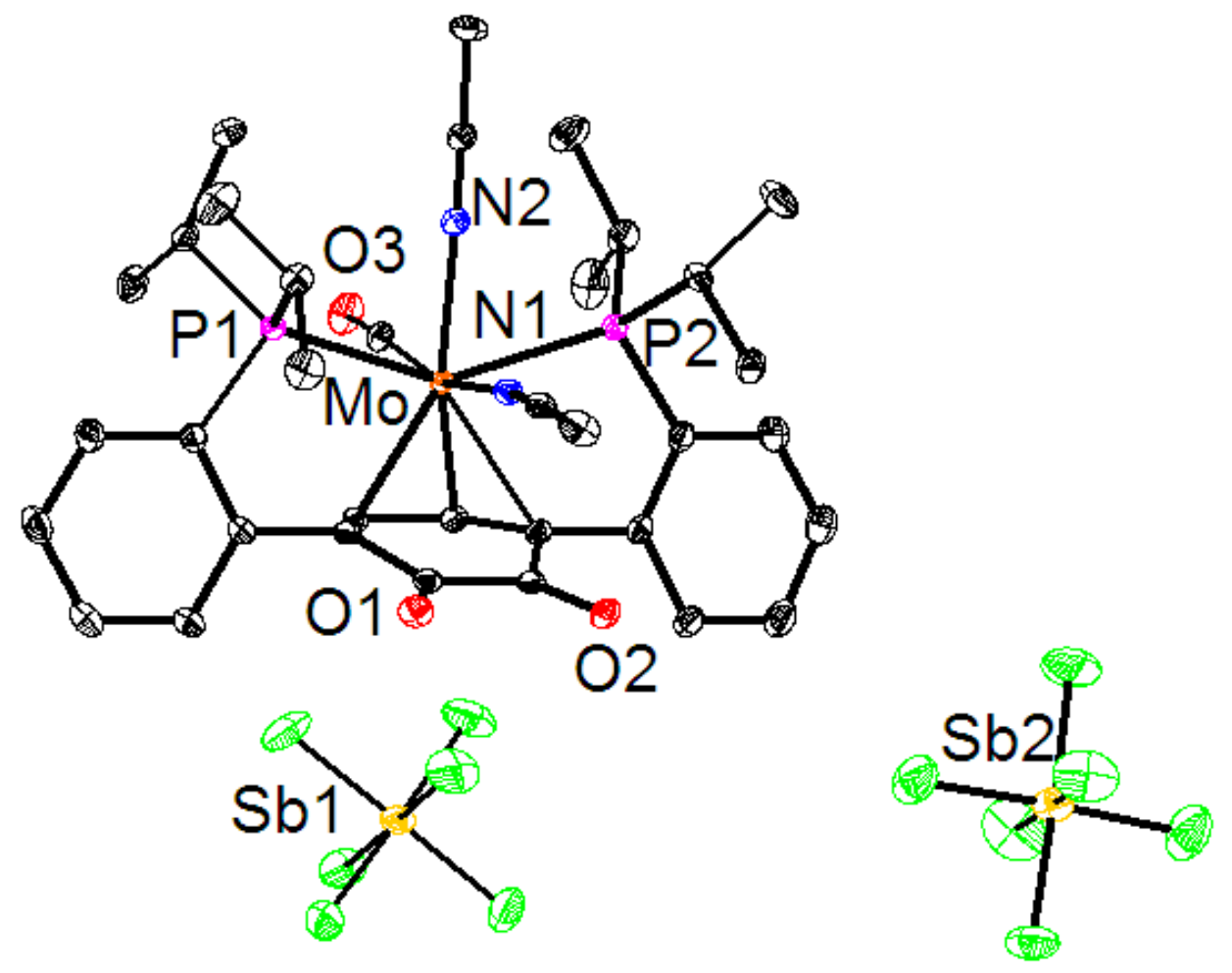

Figure S29. Structural drawing of 5a・2NCMe with 50\% probability ellipsoids.

Hydrogen atoms and solvent molecules are omitted for clarity. Carbon and fluorine atoms are shown in black and green, respectively.

Special Refinement Details for 5a: Two acetonitrile solvent molecules were highly disordered and could not be adequately modeled even with constraints. The electron density of these molecules was removed using the "solvent mask" function in Olex2. 


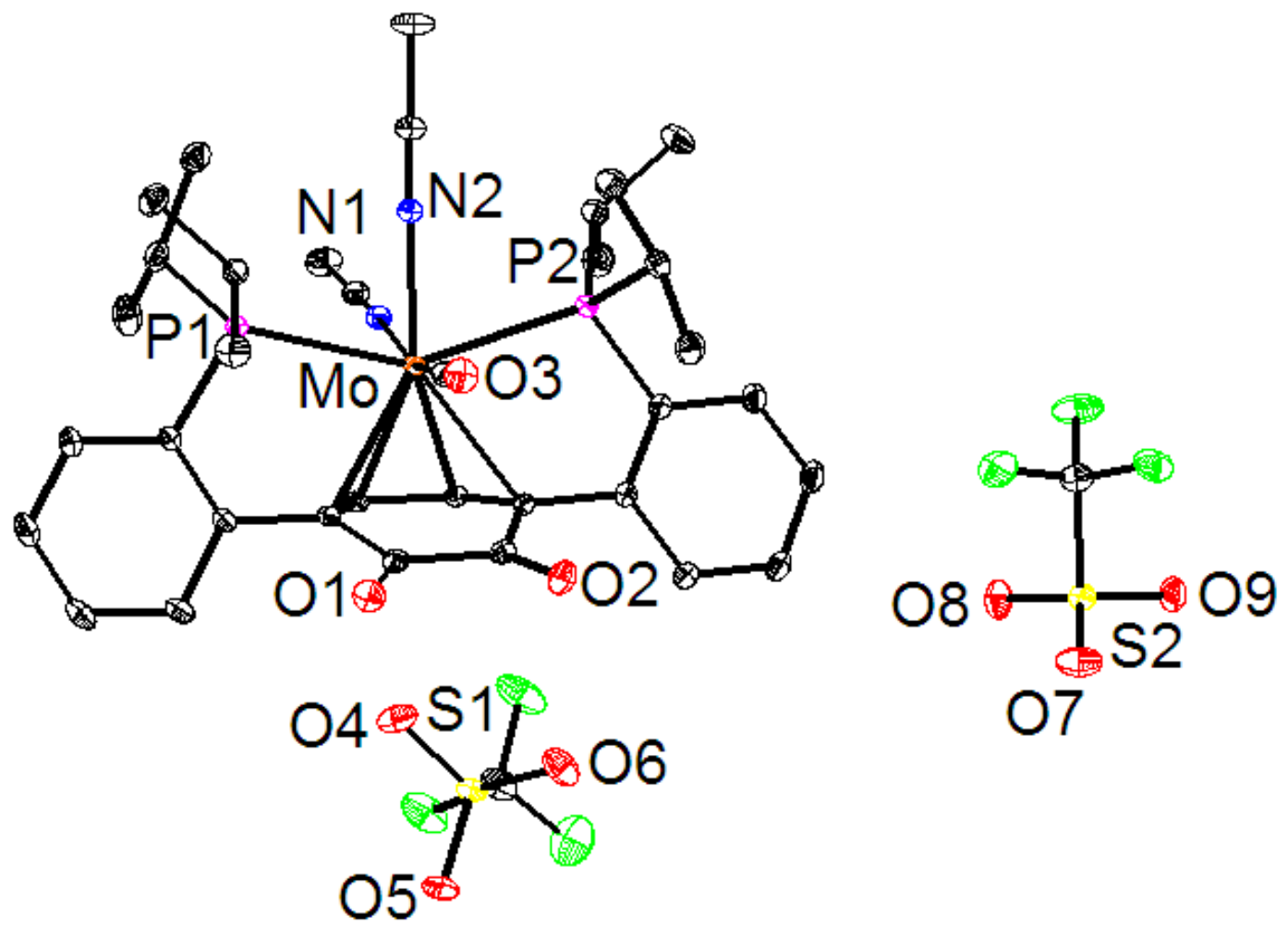

Figure S30. Structural drawing of $\mathbf{5 b}$ with $50 \%$ probability ellipsoids. Hydrogen atoms are omitted for clarity. Carbon and fluorine atoms are shown in black and green, respectively.

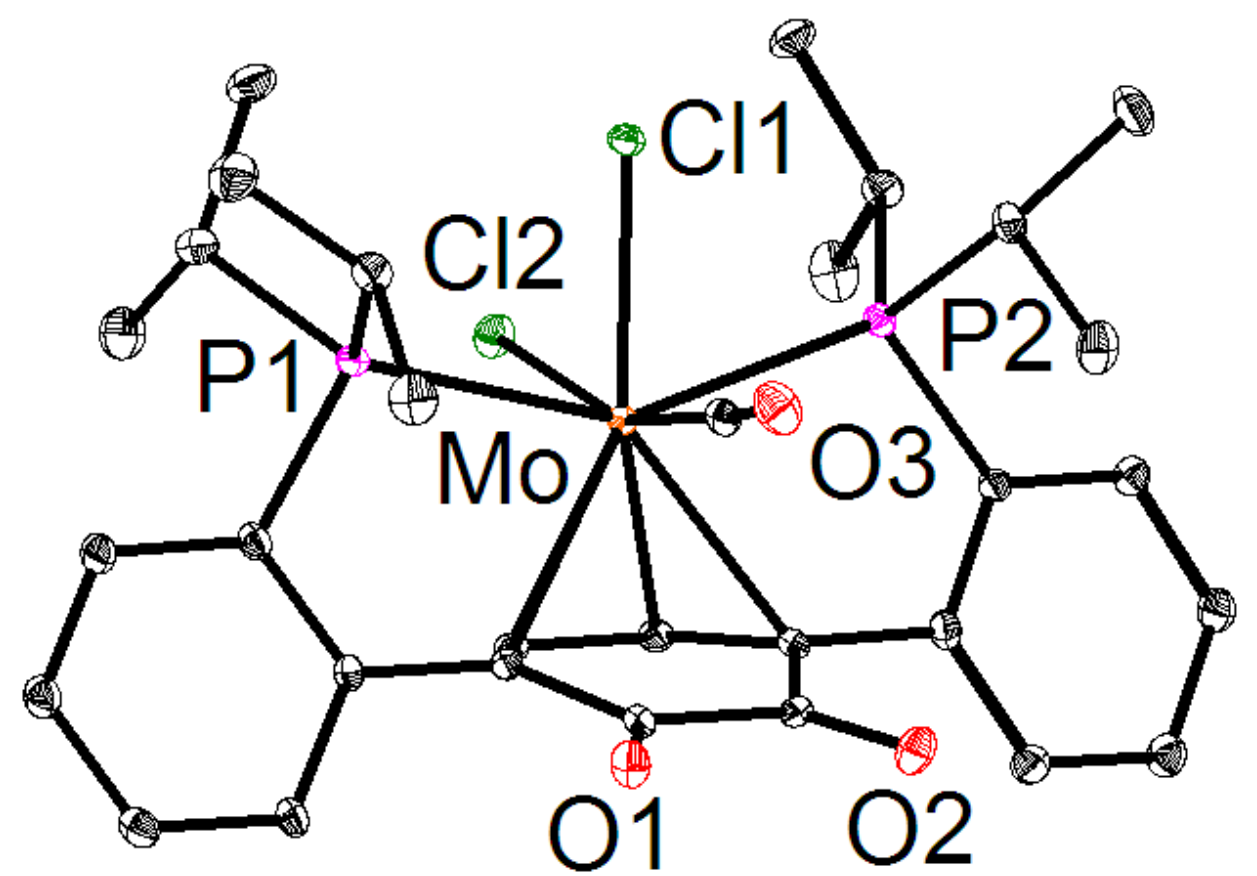

Figure S31. Structural drawing of 6 with 50\% probability ellipsoids. Hydrogen atoms are omitted for clarity. Carbon atoms are shown in black. 


\section{$V$. References}

(1) Pangborn, A.B.; Giardell, M.A.; Grubbs, R.H.; Rosen, R.K.; Timmers, F.J. Organometallics 1996, 15, 1518.

(2) Podgorsek, A.; Iskra, J. Molecules 2010, 15, 2857-2871.

(3) Schlosser, M.; Hartman, R. Angew. Chem., Int. Ed. 1973, 12, 508-509.

(4) Henthorn, J.T.; Lin, S.; Agapie, T. J. Am. Chem. Soc. 2015, 137 (4), pp 1458-1464.

(5) Balogh, V.; Fetizon, M.; Golfier, M. J. Org. Chem., 1971, 36 (10), pp 1339-1341

(6) APEX2, Version 2 User Manual, M86-E01078, Bruker Analytical X-ray Systems, Madison, WI, June 2006.

(7) Sheldrick, G.M. "SADABS (version 2008/1): Program for Absorption Correction for Data from Area Detector Frames", University of Göttingen, 2008.

(8) Sheldrick, G.M. (2008). Acta Cryst. A64, 112-122.

(9) Dolomanov, O.V. (2009). OLEX2. J. Appl. Cryst. 42, 339-341.

(10) Brandenburg, K. (1999). DIAMOND. Crystal Impact GbR, Bonn, Germany. 